\title{
A Dynamic Equilibrium Model of the US Wage Structure, 1968-1996
}

\author{
Matthew Johnson, CRA International
}

\author{
Michael P. Keane, University of Oxford and \\ University of New South Wales
}

\begin{abstract}
We develop an equilibrium model of the US labor market, fit to Panel Study of Income Dynamics data from 1968-96. Our main innovation is a finer differentiation of types of labor than in prior work (i.e., by occupation, education, gender, and age). This lets us fit wage and employment patterns better than simpler models. We obtain a good fit to wages and occupational choices over the 29-year period while also explaining college attendance rates. We use the model to assess factors driving changes in the wage structure. Occupational demand shifts and shifts in demand for college labor and female labor within occupations are key factors.
\end{abstract}

\section{Introduction}

There is a vast literature on the evolution of the US wage structure over the past 40 years. By "wage structure," we refer to patterns of wage differentials across demographic groups, usually characterized by education,

This article draws heavily on the first chapter of Matthew Johnson's dissertation at Yale. Conversations with John Roemer were instrumental in developing this project. We thank Lance Lochner, Donghoon Lee, the editor, and two referees for useful comments. We also thank participants at the 2007 Analytical Labor Economics Conference in Chicago, the 2007 Labor Econometrics Workshop in Wellington, and the 2008 European meetings of the Econometric Society in Milan. Keane's work on the project was supported by Australian Research Council grant FF0561843, and much of the work was conducted while Keane was a visiting professor at Arizona State University. For questions please contact the corresponding author, Michael P. Keane, at m.keane@unsw.edu.au. 
gender, occupation, and age. The most widely noted change over this period was the growth, since roughly 1976, of the college/high school wage premium, despite growth in the relative supply of college graduates. In the early 1990s, the consensus view of the profession attributed this growth in relative wages of more highly skilled labor to "skill-biased technical change" (SBTC) that drove up the rental price of skill in general. ${ }^{1}$

But the consensus began to crack in the early 2000s. Card and DiNardo (2002) and Eckstein and Nagypal (2004) look at the wage structure in more detail, examining not just the college premium but also (i) the college premium by age, (ii) gender and race gaps, (iii) relative wages across occupations, (iv) wage/experience profiles by education and gender, and so forth. In doing so they find many patterns that SBTC alone cannot explain. Other factors must also be at work.

For example, Card and Lemieux (2001) noted that the increase in the college premium is concentrated among young workers and that this could be explained by reduced relative supply of young college graduates. But, as they note, it is puzzling why the supply of young graduates stagnated even as the college premium soared in the 1980s. Clearly, to explain changes in wages and in education and employment choices simultaneously, one needs an equilibrium model.

With this motivation, we build an equilibrium model with labor differentiated along the four dimensions of interest noted above (education, occupation, gender, age) and with five key sources of change in the wage structure (SBTC, capital-skill complementarity, ${ }^{2}$ occupational demand shifts, demographic changes, and changing tastes for work and college). We seek to explain changes in wages and employment over the 1968-96 period at a detailed level using this model.

Our work differs from (most) earlier work in this area in three key ways: First is the fine distinction among types of labor and the attempt to fit data patterns by narrowly defined type. Second is the inclusion of several factors that may drive changes in the wage structure (i.e., most earlier work looks at only one or two factors at a time-most often SBTC and supply shifts). Third is the equilibrium nature of the analysis, accounting for both labor supply and college attendance.

With few exceptions, the prior literature on the evolution of the wage structure has been descriptive and/or partial equilibrium in nature. It has

${ }^{1}$ See, e.g., Bound and Johnson (1992), Katz and Murphy (1992), Murphy and Welch (1992), Juhn, Murphy, and Pierce (1993), Berman, Bound, and Griliches (1994), and Gottschalk and Moffitt (1994). Describing the consensus of the literature, Card and DiNardo (2002) state that "the recent rise in wage inequality is usually attributed to skill-biased technical change" (733) and that "the recent inequality literature reaches virtually unanimous agreement" (734).

${ }^{2}$ Fallon and Layard (1975) and Krusell et al. (2000) favor this story over SBTC. 
not attempted to build equilibrium models that explain the evolution of the wage structure while simultaneously explaining educational and employment/occupational choices. The notable exceptions are Heckman, Lochner, and Taber (1998a, 1998b), Lee (2005), and Lee and Wolpin (2006, 2010).

The main distinction between our work and earlier equilibrium models is that we allow many more types of labor to be imperfect substitutes in production. In Heckman et al. (1998a, 1998b), there are two types of labor: college and high school. In contrast, Lee (2005) differentiates labor by both education and occupation (white- vs. blue-collar) to get four types. In Lee and Wolpin $(2006,2010)$ there are six types that are imperfect substitutes in production (three occupations in both the goods and service sectors). Lee and Wolpin also differentiate labor by education, gender, and age, but these types differ only in tastes and/or skill levels. In contrast to our study, they are perfect substitutes in production.

Notably, Heckman et al. and Lee obtain opposite answers to the question of how an increase in the supply of college labor affects the college wage premium. Heckman et al. estimate a large effect while Lee finds that it is negligible. The difference arises because Heckman et al. do not model substitution between education types within occupations while, at the other extreme, Lee assumes that education types are perfect substitutes within occupations. Obviously one's assumptions about substitutability among types of labor make a big difference when assessing the role of supply versus demand factors in changing the college premium (as well as other aspects of the wage structure). Thus, to address such questions, we feel it is important to allow for as many types of labor as possible and to allow for as flexible a pattern of substitution between types as possible.

Even prior work on the wage structure that is partial equilibrium or descriptive in nature has, for the most part, looked at only a few types of labor, often differentiated only by education or by very broad skill groups. ${ }^{3}$ But as Card and Lemieux (2001), Card and DiNardo (2002), and Eckstein and Nagypal (2004) show, a broad perspective may lead one to miss more subtle patterns that are key to understanding what drives changes in the wage structure. They stress the importance of looking at education, gender, age, and occupation. The importance of occupation in particular has been stressed by Moscarini and Vella (2002), Kranz (2006), and Kambourov and Manovskii $(2008,2009$ a, 2009b). They argue that occupation is a better measure of skill than education and that occupational demand shifts are crucial for understanding changes in the wage structure. This motivates us to (i) differentiate labor by occupation and (ii) allow for occupational de-

\footnotetext{
${ }^{3}$ As an exception, in one analysis, Katz and Murphy (1992) looked at labor differentiated into 64 education, gender, and age cells. This allowed them to see that SBTC could not explain narrowing of the male/female wage gap.
} 
mand shifts. As we will show, our model does a good job of explaining wage changes by occupation.

To anticipate a key finding, an awkward fact for the pure SBTC hypothesis is that, while wages and employment of high school males began to fall in the mid-1970s, high school females did well on both dimensions. Eckstein and Nagypal (2004) note the importance of this pattern. Our model explains it by (i) imperfect substitution of genders, (ii) a demand shift toward (heavily female) service occupations, and (iii) technical change favoring women within occupations.

Notably, Lee and Wolpin (2010) explain increased relative wages of women via ( $a$ ) an exogenous decline in fertility and $(b)$ a shift in demand toward service occupations. This leads to skill upgrading: women expect to work more so they acquire more human capital. However, as males and females are perfect substitutes in their model, they may have difficulty explaining the increase in relative wages of women within education/occupation cells that is a key feature of the data. This is another motivation for a finer differentiation among types of labor in production.

Thus, our main goal is to estimate an equilibrium model of the labor market with many more types of labor than in prior work. Specifically, we differentiate labor by education (college vs. high school), gender, age (four 10-year intervals from 25 to 64), and 10 occupations (roughly the one-digit level). This gives $2 \cdot 2 \cdot 4 \cdot 10=160$ types of labor that enter a multilevel nested constant elasticity of substitution (CES) aggregate production technology. The greater richness of the model may lead to a more reliable assessment of what factors were important in driving changes in the wage structure.

We fit our model to Panel Study of Income Dynamics (PSID) data from 1968-96 on (annual) wages and employment of each of the 160 types of labor. In addition, for each cohort of 19-year-old youths from 1968 to 1990, we fit the fraction of males and females from each of four parental background types who choose to attend college. A key challenge for our model is to explain the stagnation, noted by Card and Lemieux (2001), of college attendance rates in the 1970s and 1980s despite the rising college wage premium. As we see in figure 1, the model does a good job of tracking this pattern. And, in most cases, the model also does quite a good job of tracking the wage and employment paths for all 160 types of labor over the 29 years of our data.

The rest of the article is organized as follows: Section II presents our model, and Section III describes the PSID data used in estimation. Sections IV-VI present our estimation results. Section VII discusses the fit of the model and in so doing describes many interesting patterns in the data. Section VIII presents counterfactual simulations, and Section IX presents conclusions. 




Model

PSID

- - - - - . \% Parent Educ

FIG. 1.-Education choice at age 19 (percentage attending college) 


\section{An Overlapping-Generations Equilibrium Model of the Labor Market}

In each year the population of the model economy consists of overlapping generations of individuals aged 19-64. Youths enter the economy at age 19 and decide whether or not to attend college. At that point, there are eight types of people, differentiated by gender and four levels of parental education, that is, whether the best-educated parent's completed education was less than high school $(<\mathrm{HS})$, high school (HS), some college (SC), or college (COL). These eight types have different "costs" of college attendance. The competitively determined college earnings premium determines the proportion of each type that attends. Thus, the supply of college labor is endogenous. We describe the decision rule for college attendance in detail in Section II.C.

All individuals (regardless of their schooling decision) enter the labor force at age $25 .{ }^{4}$ After that, a worker's type is determined solely by gender, age, and own education (i.e., parents' education no longer matters). ${ }^{5}$ In each year (through age 64) workers choose either working in the home sector or working in one of 10 (roughly one-digit) occupations. Workers make occupational choices on the basis of the current vector of competitively determined occupational wages, which is education-gender-age specific. Workers also have type-specific nonpecuniary payoffs to each occupation. We describe the occupational choice decision rule in detail in Section II.B.

Given the occupational choice decision, the model contains 160 types of labor that are allowed to be imperfect substitutes in production. Types are distinguished by education (college vs. high school), gender, age (four categories), and occupation (10 categories). These 160 types of labor, along with the aggregate capital stock, are combined, via a nested CES production function, into aggregate output. We describe the production function in detail in Section II.A.

In each year, the equilibrium of the economy is a 160 -vector of occupationeducation-age-gender-specific wages such that the market for each skill type clears. Let $X_{g, e, a, t}$ denote the type $(g, e, a)$-specific aggregate supply of labor to the economy at time $t$, where $g$ denotes gender, $e$ denotes education, and $a$ denotes age. This is governed by the sizes, gender composition, and educational choices of past cohorts. Let $L_{g, e, a, k, t}$ denote the type $(g, e, a)-$ specific supply of labor to occupation $k$ at time $t$. This is governed by the function $D_{k}^{g, e, a}(\cdot, \cdot)$ :

$$
L_{g, e, a, k, t, t}=D_{k}^{g, e, a}\left[\left\{w_{g, e, a, k, t, t}\right\}_{k=1}^{10}, X_{g, e, a, a, t}\right]
$$

\footnotetext{
${ }^{4}$ We assume that work starts at age 25 largely because of data limitations that we discuss in Sec. III.

${ }^{5}$ This is consistent with results in the study by Geweke and Keane (2000), who find, using a subsample of these same data, that parental background is insignificant in earnings functions that control for own education and experience.
} 
which says that the supply of $(g, e, a)$ labor to occupation $k$ depends on wages $\left\{w_{g, e, a, k, t}\right\}_{k=1,10}$, aggregate supplies $\left\{X_{g, e, a, t}\right\}$, and group-specific tastes for occupations (and the home sector).

Equilibrium wages are given by partials of the aggregate production function, evaluated at the aggregate capital stock $A_{t}$ and the type-specific labor aggregates $\left\{L_{g, e, a, k, t}\right\}$ :

$$
w_{g, e, a, k, t}=f_{L_{g, k e, a t}}\left(A_{t},\left\{\left\{\left\{\left\{D_{k}^{g, e, a}\left[\left\{w_{g, e, a, k, t}\right\}_{k=1}^{10}, X_{g, e, a, t}\right]\right\}_{k=1}^{10}\right\}_{g=1}^{2}\right\}_{e=1}^{2}\right\}_{a=1}^{4}\right) .
$$

Thus, at the equilibrium wage vector, individual labor supply decisions give type-specific labor supplies to occupations that equate wages to marginal products for each type in each occupation.

Solving for equilibria in all years from 1968 to 1996 is an iterative sequential process. In each year, the equilibrium wage vector solves a 160 -dimensional fixed-point problem. We must solve these problems sequentially; that is, the solution in 1968 determines the supply of college labor that enters in 1974 and so forth. ${ }^{6}$ We present the solution procedure in appendix A, available in the online version of the article. The solution serves as input to estimation, which we discuss in Section II.E after describing the model in detail.

\section{A. Form of the Production Technology}

The model incorporates imperfect substitution among labor inputs via a nested CES production function with several levels. One might order CES nests of labor differentiated by occupation, education, gender, and age in many ways, but we view our ordering as natural. We place occupations in the upper-level nests, as labor of multiple occupations must typically be combined to produce products or services - not necessarily labor of different education, gender, or age levels. We felt that education should come next, as it seems intuitive that education is the primary determinant of the quality of an occupation's workers. The ordering of gender versus age is not so obvious. We chose to put gender next and age last, and the model fits well that way.

At the top level, aggregate output depends on capital $(A)$ and CES aggregates of "skilled" and "unskilled" labor, denoted $\mathrm{EMP}_{s}$ and $\mathrm{EMP}_{u}$, respectively. Thus we have

$$
Y=f(\cdot)=\beta\left\{\lambda_{s}\left[\lambda_{A} A^{\rho_{s}}+\left(1-\lambda_{A}\right) \operatorname{EMP}_{s}^{\rho_{s}}\right]^{\rho_{u} / \rho_{s}}+\left(1-\lambda_{s}\right) \operatorname{EMP}_{u}^{\rho_{u}}\right\}^{1 / \rho_{u}},
$$

where $\beta=\exp [b(0)+b(1) \cdot t]$ is a scale and technical progress (total factor productivity $[\mathrm{TFP}]$ ) parameter. The $\lambda$ 's are "share" parameters that govern income shares for each input, while the $\rho$ 's $(\rho<1)$ govern the elasticity

${ }^{6}$ We take the initial 1968 distribution of types of labor $X_{g, e, a, 1968}$ as exogenous. Then, $X$ evolves as a result of the demographics and educational choices of incoming cohorts. Because we assume that the cohort of 19-year-olds who make college choices in 1968 do not enter the labor market until age 25, we actually take $X$ to be exogenously given up until 1974. 
of substitution between inputs. Of course the $\lambda$ 's translate literally into income shares only in the Cobb-Douglas special case that arises if $\rho \rightarrow 0$ (see Arrow et al. 1961).

The elasticity of substitution between capital and skilled labor is $\sigma_{s}=$ $1 /\left(1-\rho_{s}\right)$, while that between the capital-skill composite and unskilled labor is $\sigma_{u}=1 /\left(1-\rho_{u}\right)$. We have capital-skill complementarity, meaning that growth in the capital stock increases relative demand for skilled labor, if $\rho_{u}>\rho_{s}$, which implies $\sigma_{u}>\sigma_{s}$. Our top-level setup is similar to that in Fallon and Layard (1975) and Krusell et al. (2000), except we define skill along occupational (not educational) lines.

At the second-level nest we have skilled $\left(\mathrm{EMP}_{s}\right)$ and unskilled $\left(\mathrm{EMP}_{u}\right)$ labor aggregates:

$$
\begin{aligned}
& \mathrm{EMP}_{s}=\left[\lambda_{1} \mathrm{EMP}_{1}^{\rho_{H}}+\left(1-\lambda_{1}\right) \mathrm{EMP}_{2}^{\rho_{H}}\right]^{1 / \rho_{H}}, \\
& \mathrm{EMP}_{u}=\left[\lambda_{u} \mathrm{EMP}_{u 1}^{\rho_{L}}+\left(1-\lambda_{u}\right) \mathrm{EMP}_{u 2}^{\rho_{L}}\right]^{1 / \rho_{L}} .
\end{aligned}
$$

Skilled labor combines labor in occupations 1 and 2 (professionals and managers). Unskilled labor combines labor in the service and blue-collar occupations, $\mathrm{EMP}_{u 1}$ and $\mathrm{EMP}_{u 2}$, respectively.

At the next level, the service sector input $\left(\mathrm{EMP}_{u 1}\right)$ is a CES aggregate of employment in occupations 3-6 (technicians, sales, clerical, and narrow services), while blue-collar $\left(\mathrm{EMP}_{u 2}\right)$ is a CES aggregate of occupations 7-10 (craft workers, operatives, transport operatives, and laborers):

$$
\begin{aligned}
& \mathrm{EMP}_{u 1}=\left[\lambda_{3} \mathrm{EMP}_{3}^{\rho_{u 1}}+\lambda_{4} \mathrm{EMP}_{4}^{\rho_{u 1}}+\lambda_{5} \mathrm{EMP}_{5}^{\rho_{u 1}}+\left(1-\lambda_{3}-\lambda_{4}-\lambda_{5}\right) \mathrm{EMP}_{6}^{\rho_{u 1}}\right]^{1 / \rho_{u 1}} \\
& \mathrm{EMP}_{u 2}=\left[\lambda_{7} \mathrm{EMP}_{7}^{\rho_{u 2}}+\lambda_{8} \mathrm{EMP}_{8}^{\rho_{u 2}}+\lambda_{9} \mathrm{EMP}_{9}^{\rho_{u 2}}+\left(1-\lambda_{7}-\lambda_{8}-\lambda_{9}\right) \mathrm{EMP}_{10}^{\rho_{u 2}}\right]^{1 / \rho_{u 2}}
\end{aligned}
$$

Thus, the parameter $\rho_{u 1}$ governs substitution among the four service sector occupations, while $\rho_{u 2}$ governs substitution among the four blue-collar occupations.

Next we consider occupation-level effective labor inputs. Each occupational labor input is assumed to consist of an aggregate of college and high school labor as follows:

$$
\mathrm{EMP}_{k}=\left[\mu_{k} \mathrm{HS}_{k}^{\rho_{c}}+\left(1-\mu_{k}\right) \mathrm{COL}_{k}^{\rho_{c}}\right]^{1 / \rho_{e}} \quad \text { for } k=1,10
$$

where $\mathrm{HS}_{k}$ and $\mathrm{COL}_{k}$ denote high school and college type labor in occupation $k$, respectively. Note that the CES share parameters $\mu_{k}$ are allowed to vary across the 10 occupations, but the education substitution parameter $\rho_{e}$ is assumed to be common across all occupations. 
At the next nesting level, the amounts of college and high school labor supplied to each occupation are assumed to consist of male and female workers. Thus we have

$$
\begin{aligned}
\mathrm{HS}_{k} & =\left[\xi_{k}\left(\mathrm{HS}_{k}^{\text {male }}\right)^{\rho_{g}}+\left(1-\xi_{k}\right)\left(\mathrm{HS}_{k}^{\text {female }}\right)^{\rho_{g}}\right]^{1 / \rho_{g}} \\
\mathrm{COL}_{k} & =\left[\gamma_{k}\left(\mathrm{COL}_{k}^{\text {male }}\right)^{\rho_{g}}+\left(1-\gamma_{k}\right)\left(\mathrm{COL}_{k}^{\text {female }}\right)^{\rho_{g}}\right]^{1 / \rho_{g}}
\end{aligned}
$$

for $k=1,10$. The elasticity of substitution between genders is common across occupation/education cells and is governed by $\rho_{g}$. But the share parameters $\xi_{k}$ and $\gamma_{k}$ can differ by occupation/education level.

The final CES nest aggregates labor in four different age groups: 25-34, 35-44, 45-54, and 55-64. These generate four gender/education level inputs as follows:

$$
\begin{aligned}
& \mathrm{HS}_{k}^{\text {male }}=[ \tau_{1 k}\left(\mathrm{HS}_{k, 25-34}^{\text {male }}\right)^{\rho_{a}}+\tau_{2 k}\left(\mathrm{HS}_{k, 35-44}^{\text {male }}\right)^{\rho_{a}}+\tau_{3 k}\left(\mathrm{HS}_{k, 45-54}^{\text {male }}\right)^{\rho_{a}} \\
&\left.+\left(1-\tau_{1 k}-\tau_{2 k}-\tau_{3 k}\right)\left(\mathrm{HS}_{k, 55-64}^{\text {male }}\right)^{\rho_{a}}\right]^{1 / \rho_{a}} \\
& \mathrm{HS}_{k}^{\text {female }}=[ \sigma_{1 k}\left(\mathrm{HS}_{k, 25-34}^{\text {female }}\right)^{\rho_{a}}+\sigma_{2 k}\left(\mathrm{HS}_{k, 35-44}^{\text {female }}\right)^{\rho_{a}}+\sigma_{3 k}\left(\mathrm{HS}_{k, 45-54}^{\text {female }}\right)^{\rho_{a}} \\
&\left.+\left(1-\sigma_{1 k}-\sigma_{2 k}-\sigma_{3 k}\right)\left(\mathrm{HS}_{k, 55-64}^{\text {female }}\right)^{\rho_{a}}\right]^{1 / \rho_{a}} \\
& \mathrm{COL}_{k}^{\text {male }}=\left[\nu_{1 k}\left(\mathrm{COL}_{k, 25-34}^{\text {male }}\right)^{\rho_{a}}+\nu_{2 k}\left(\mathrm{COL}_{k, 35-44}^{\text {male }}\right)^{\rho_{a}}+\nu_{3 k}\left(\mathrm{COL}_{k, 45-54}^{\text {male }}\right)^{\rho_{a}}\right. \\
&+\left.\left(1-\nu_{1 k}-\nu_{2 k}-\nu_{3 k}\right)\left(\mathrm{COL}_{k, 55-64}^{\text {male }}\right)^{\rho_{a}}\right]^{1 / \rho_{a}} \\
& \mathrm{COL}_{k}^{\text {female }}=\left[\varpi_{1 k}\left(\mathrm{COL}_{k, 25-34}^{\text {female }}\right)^{\rho_{a}}+\varpi_{2 k}\left(\mathrm{COL}_{k, 35-44}^{\text {female }}\right)^{\rho_{a}}+\varpi_{3 k}\left(\mathrm{COL}_{k, 45-54}^{\text {female }}\right)^{\rho_{a}}\right. \\
&+\left.\left(1-\varpi_{1 k}-\varpi_{2 k}-\varpi_{3 k}\right)\left(\mathrm{COL}_{k, 55-64}^{\text {female }}\right)^{\rho_{a}}\right]^{1 / \rho_{a}}
\end{aligned}
$$

where $k=1,10$ denotes occupation. The degree of substitutability between age groups is common across occupation/education/gender cells and is governed by the single parameter $\rho_{a}$. But the share parameters $\tau_{k}, \sigma_{k}, \nu_{k}$, and $\varpi_{k}$ are allowed to differ by occupation/gender/education level. As we see in (8), only the labor aggregates for education/gender/occupation/age cells enter our model. (The model is fit to these 160 aggregate cells over the 29 years of the sample.)

As is standard in the wage structure literature, we let the share parameters vary over time to capture SBTC and other factors that shift demand for different types of labor. Specifically, we let them follow low-order polynomials in time, using logistic transformations to constrain them to lie in the $(0,1)$ interval. For example, in the top-level nest (eq. [3]), we specify that 


$$
\lambda_{i}=\frac{\exp \left(\lambda_{i 0}+\lambda_{i 1} t+\lambda_{i 2} t^{2}+\lambda_{i 3} t^{3}+\lambda_{i 4} t^{4}\right)}{1+\exp \left(\lambda_{i 0}+\lambda_{i 1} t+\lambda_{i 2} t^{2}+\lambda_{i 3} t^{3}+\lambda_{i 4} t^{4}\right)}, \quad i=s, A .
$$

Thus, the capital share parameter $\lambda_{A}$ and the capital/skilled labor aggregate share $\lambda_{s}$ are allowed to follow fourth-order polynomials in time. Similar expressions apply to the other share parameters.

As we will see below, fourth-order polynomials provide a good fit to the data. This is perhaps not surprising for two reasons. First, it is plausible that technical change and/or shifts in relative demand for different types of labor would occur gradually (and smoothly) over time. Second, the share parameters may also be shifted by short-run macro shocks. But the sample period contained only two large macro shocks: the severe recessions of 1974-75 and 1982. ' Thus, it is plausible that low-order polynomials are adequate to capture the labor demand shifts over the 29-year sample period, as the share parameter trends are unlikely to have had more than a few major turning points.

One detail involves the share parameters for the different age groups in equations (8). ${ }^{8}$ There are 120 such parameters. If each is allowed to follow a fourth-order polynomial, it gives 600 parameters. To avoid such proliferation, we impose two restrictions: (1) Occupations within each of the three broad occupational groups (i.e., skilled labor, services, and blue-collar) have common intercepts in their age-share time polynomials. This reduces the number of intercepts from 120 to 36. (2) Linear and higher-order terms in the age-share polynomials are assumed common across all 10 occupations within each of the 12 education/gender/age groups. This reduces the number of higher-order terms from 480 to $48 .^{9}$ Also, in many cases we found that fourth-order polynomials were not necessary to obtain a good fit to the data. In these cases we stopped at the third order.

\section{B. Occupational Choice}

In each period, workers aged 25-64 choose among 11 alternatives (10 paid occupations and home work). Recall that there are 16 types of workers, distinguished by age-gender-education, and each type faces a different 10 -vector of occupational wages. Types also differ in tastes for working in

7 There were three much milder recessions in 1969:4-1970:4, 1980:1-1980:3, and 1990:3-1991:1.

${ }^{8}$ Equations (8a)-(8d) each contain four share parameters that sum to one, so they contain only three free parameters each. We impose the summing to one constant using a multinomial logit (MNL) transformation. The same is true of eq. (5).

9 Assumption 2 means that if the income share of an age group within a gender/ education category rises in one occupation, it will tend to rise in all occupations. This does not mean that income shares of gender/education groups will move similarly across occupations. How gender and education shares move is determined by parameters in (3)-(7). 
each occupation. Workers choose among the alternatives on the basis of the wage vector and their tastes. ${ }^{10}$ The utility to a worker conditional on choice of occupation $k$ at time $t$ is given by

$$
U(g, e, a)_{k, t}=\alpha_{0, g, e, k}+\alpha_{1} w_{g, e, a, k, t}+\alpha_{2}\left(e-\bar{e}_{k, t}\right)^{2}+\alpha_{3} \operatorname{Pr}\left[d_{k, t-1}=1\right]+\varepsilon_{k, t} .
$$

Here, $\alpha_{0, g, e, k}$ is a nonpecuniary reward that a worker of gender $g$ and education level $e$ receives in occupation $k$. This is assumed to be age and calendar time invariant. In the second term, $\alpha_{1}$ is a parameter and $w_{g, e, a, k, t}$ is the wage for a worker of type $(g, e, a)$ in occupation $k$ at time $t$.

The third term is the difference between a worker's own education level and the average level of workers in occupation $k$. This captures that workers may receive a psychic benefit (cost) from working with other workers who are similar to (different from) themselves (e.g., college workers are willing to give up some earnings for more mentally stimulating employment). ${ }^{11}$ In the fourth term, $d_{k, t-1}$ is a $1 / 0$ indicator for whether occupation $k$ was chosen at $t-1$. Thus, $\operatorname{Pr}\left[d_{k, t-1}=1\right]$ is the proportion of workers who chose occupation $k$ in the previous year. This is included to capture persistence in occupational choices. ${ }^{12}$ Finally, the taste shock $\varepsilon_{k, t}$ is assumed to be independent and identically distributed (iid) extreme value. This gives simple MNL forms for the choice probabilities.

The utility of the home alternative differs by age, gender, and calendar time as follows:

$$
U(g, e, a)_{0, t}=\alpha_{b 0}+\alpha_{b 1} \cdot t+\left(\alpha_{b 0, f}+\alpha_{b 1, f} \cdot t\right) \cdot I(g=f)+\alpha_{g, a}+\varepsilon_{b, t} \cdot
$$

Here $\alpha_{b 0}$ and $\alpha_{b t}$ capture the level and trend in the value of home time for men, while $\alpha_{b 0, f}$ and $\alpha_{b 1, f}$ capture deviations in the level and trend for women. We expect level and trend differences by gender, given the initially much lower but rapidly rising level of female employment over the sample period. Of course, the trend for women arises not just from changes in tastes but also from changes in fertility and marriage market opportunities, which we do not model explicitly.

${ }^{10}$ As wages depend only on gender, education, and age — and not on accumulated occupation-specific or general work experience-workers do not need to consider any impact of current choices on future wage offers.

${ }^{11}$ If this effect exists and we ignore it, labor supply elasticities will be biased downward. Also, given this effect, the nonpecuniary reward terms $\alpha_{0, g, e, k}$ in (10) should be interpreted as net of the rewards from being with similar workers.

${ }^{12}$ Persistence may arise because of habit persistence or labor adjustment costs at the individual or aggregate level. For example, a structural motivation for $\alpha_{3}$ may be that it is easier to obtain offers from larger sectors. This would hinder small sectors from growing and discourage large sectors from shrinking, generating persistence in size of sectors. 
Note that the model has multiple means to explain increasing employment of women, not just changing "tastes" in (11). For instance, there may be technical change or demand shifts that drive up income shares for the service sector occupations, leading in turn to higher wages in (10). Or there may be female-biased technical change within occupations (eq. [7]).

The term $\alpha_{g, a}$ is a gender/age-specific shifter of the value of home time. This is meant to capture the lower market participation rate of older workers (as they retire). Finally, $\varepsilon_{k, t}$ is again an independent type I extreme-value error term.

Given the setup in (10)-(11), the proportions of workers of type $(g, e, a)$ who choose to work in occupation $k$, or who choose the home sector 0 , are given by the MNL expressions

$$
\mathrm{P}\left(d_{k t}=1 \mid g, e, a\right)=\frac{\exp \left[U(g, e, a)_{k, t}\right]}{\sum_{k=0}^{10} \exp \left[U(g, e, a)_{k, t}\right]} \text { for } k=0,10 .
$$

We are now in a position to state the specific form of the supply function in equation (1):

$$
L_{g, e, a, k, t}=D_{k}^{g, e, a}\left[\left\{w_{g, e, a, k, t,}\right\}_{k=1}^{K}, X_{g, e, a, t}\right]=\mathrm{P}\left(d_{k t}=1 \mid g, e, a\right) \cdot X_{g, e, a, t} .
$$

Finally, we emphasize that the parameters of the individual choice process (10)-(11) are identified from aggregate choice frequencies of workers in each of our 16 age-gender-education cells (and how they vary over the 29 years of the data).

\section{Educational Choice}

At age 19, the members of each entering cohort decide whether to attend college. Then, at age 25, they enter the labor market, as either college or high school workers. Recall that youths differ in parental background, denoted by $b \in\{<\mathrm{HS}, \mathrm{HS}, \mathrm{SC}, \mathrm{COL}\}$ and gender $g$. The value function associated with college attendance for a youth of type $(g, b)$ is given by

$$
\begin{aligned}
V_{t}^{C}(g, b)= & \left.\phi_{1 m} I(g=m)+\phi_{1 f} I(g=f)\right] \cdot E\left[\sum_{a=25}^{64} \delta^{a-25} w_{g, \mathrm{COL}, a}\right]-\phi_{2 b} \\
& +\left(\phi_{3}+\phi_{4} t+\phi_{5} t^{2}\right) I(g=f)+\left(\phi_{6} t+\phi_{7} t^{2}\right) I(g=m) \\
& +\phi_{8} \text { Cost }+\varepsilon_{C, t} .
\end{aligned}
$$

Here, $E\left[\sum_{a=25}^{64} \delta^{a-25} w_{g, \mathrm{COL}, a}\right]$ is the expected present value of lifetime income (from age 25 to the end of the working life at age 64) for college workers of gender $g$. The second term, $\phi_{2 b}$, is a cost of college that is specific to a youth's parental background type $b$ (this is similar to Heckman et al.'s [1998a, 1998b] approach, except they define types using Armed Forces Qual- 
ification Test [AFQT] quartiles instead of parents' education). The terms $\phi_{3}$ through $\phi_{7}$ accommodate differences in tastes for college between males and females, as well as allowing for quadratic trends in these tastes. ${ }^{13}$ The term Cost is a measure of tuition costs, and $\varepsilon_{c, t}$ is a type I extreme-value error. The $\varepsilon_{c, t}$ capture unobserved heterogeneity in costs of/tastes for college.

There are two critical things to note about $E\left[\sum_{a=25}^{64} \delta^{a-25} w_{g, \mathrm{COL}, a}\right]$. First, youths take this expectation assuming that the current-period equilibrium wage vector will persist into the future. This is a key simplifying assumption that differentiates our work from that of Heckman et al. (1998a, 1998b) and Lee and Wolpin (2006, 2010), who assume that youths forecast the future path of equilibrium wages. Our assumption makes model solution much simpler, which allows us to have many more types of labor that are imperfect substitutes. ${ }^{14}$

Second, the expectation is taken using the probabilities in (12) to integrate over work and occupational choices a person of type $(g, \mathrm{COL})$ is likely to make over the life cycle. For example, women tend to have lower expected earnings than men because they tend to spend less time employed.

The coefficient $\phi_{1}$ on expected present value of earnings differs for males versus females. The constant $\phi_{3}$ and trend terms $\phi_{4}$ and $\phi_{5}$ also shift the value of college for women. This accounts for gender differences in tastes for college and/or the nonpecuniary rewards from college (e.g., more of the return to college for women may come in the marriage market; see Keane and Wolpin 2010).

The "cost" terms $\phi_{2 b}$ for $b \in\{<\mathrm{HS}, \mathrm{HS}, \mathrm{SC}, \mathrm{COL}\}$ capture that youths of different social backgrounds face different psychic and monetary costs of college. For example, youths with less educated parents may be less prepared for college, so attendance would require greater effort, or they may

${ }^{13}$ College graduates also receive the expected present value of nonpecuniary rewards for the occupations they expect to work in (the $\alpha_{0, g, e, k}$ in eq. [10]), which differ from those of high school graduates. As the $\alpha_{0, g, e, k}$ are time invariant and occupational choice probabilities vary slowly, these present values will largely be subsumed in the $\phi$ parameters.

${ }^{14}$ We see no philosophical reason to assume that youths can forecast future wages. Even the assumption that they know the current wage structure exactly is strong (see Manski 1993; Betts 1996; Dominitz and Manski 1996), though recent work by Martins (2006), who surveys Portuguese college students, suggests that "students have a relatively good understanding of [current] market [wage] rates" (1). Perfect foresight (as in Heckman et al.'s study) or rational expectations (as in Lee and Wolpin's) are often invoked not because we believe them but to make model solution simpler. But here, if youths forecast future wages, it vastly increases computational difficulty (e.g., in Lee and Wolpin [2006, 2010], only six rental prices need be forecast [as there are six types], but even then they can solve only for an approximate equilibrium). Of course, our myopia assumption may break down given a policy change that leads to large predictable changes in the college wage premium (as people would presumably incorporate large enough changes into their planning). 
have less taste for education. As for monetary costs, while (13) contains tuition, this fails to capture other costs of college such as room and board. Nor do available data capture financial aid well. And even accurate cost data fail to capture that less educated parents provide less financial aid for youths to attend college (see Leslie 1984; Keane and Wolpin 2001).

Finally, the value associated with stopping school at the high school level is given by

$$
V_{t}^{\mathrm{HS}}(g, b)=\left[\phi_{1 m} I(g=m)+\phi_{1 f} I(g=f)\right] \cdot E\left[\sum_{a=25}^{64} \delta^{a-25} w_{g, \mathrm{HS}, a}\right]+\varepsilon_{\mathrm{HS}, t} .
$$

This value function again involves the expected present value of lifetime earnings, in this case for workers with a high school education. ${ }^{15} \mathrm{We}$ do not repeat any other terms from (13), as $\phi_{2 b}$ through $\phi_{7}$ can all be interpreted as utilities or costs of college attendance relative to stopping at high school.

Given (13) and (14), the probability a youth of type $(g, b)$ decides to attend college is

$$
\mathrm{P}_{t}(e=\mathrm{COL} \mid g, b)=\frac{\exp \left[V_{t}^{C}(g, b)\right]}{\exp \left[V_{t}^{\mathrm{HS}}(g, b)\right]+\exp \left[V_{t}^{C}(g, b)\right]} .
$$

After the college decision, workers enter the labor market at age 25. Then, wages are influenced only by a worker's own education, age, and gender (parental background no longer matters). ${ }^{16}$

Given (15), the number of college workers of gender $g$ entering the economy at time $t$ is

$$
\mathrm{COL}_{g, t}^{25}=\sum_{b=1}^{4} N_{g, b, t-6}^{19} \cdot \mathrm{P}_{t-6}(e=\mathrm{COL} \mid g, b) .
$$

Here $N_{g, b, t-6}^{19}$ is the number of 19 -year-olds of gender $g$ and parental education $b$ who enter the model at time $t-6$. We take these entering cohort sizes, which vary substantially over time (see fig. 1, dashed lines), as exogenous. This is important for identification (see Sec. II.E).

Ignoring mortality, the stock of 25-34-year-old college workers evolves as follows:

${ }^{15}$ If noncollege types work more than college types prior to age 25 , we will overstate the college lifetime earnings premium. But this should be largely subsumed in the intercept of the college attendance decision rule and so have little impact on our results.

${ }^{16}$ Thus, a worker's wage depends on his or her own schooling (two levels) and not on parents' schooling (four levels). This may seem strong, but it is consistent with the literature on Mincer earnings functions, where earnings are typically specified as a function of own education and experience, and parents' schooling is rarely controlled for. 
$\mathrm{COL}_{25-34, t}^{g}=\mathrm{COL}_{25-34, t-1}^{g}+\mathrm{COL}_{25, t}^{g}-\mathrm{COL}_{35, t}^{g} \quad$ for $g=$ male, female.

Stocks of college and high school workers in the other age groups evolve in the same way. Attrition is also incorporated, using life tables, but we ignore it here to simplify notation.

\section{Equilibrium Determination of the Capital Stock}

We estimate two versions of the model, with capital treated as exogenous or endogenous. In the latter case, the optimal capital stock at $t$ equates the marginal product of capital evaluated at current labor input levels to an exogenous rental price of capital $r_{t}^{C}$. Formally,

$$
r_{t}^{C}=\partial Y_{t}\left(A_{t},\left\{\left\{\left\{\left\{L_{g, e, a, k, t}\right\}_{g=1}^{2}\right\}_{e=1}^{2}\right\}_{a=1}^{4}\right\}_{k=1}^{10}\right) / \partial A_{t} .
$$

The term $r_{t}^{C}$ can be viewed as a world price of capital not determined in the model (i.e., it does not depend on model factor supplies). It is assumed to evolve according to a fourth-order polynomial in time. In estimating this version of the model, we attempt to fit the capital stock data from 1968-96.

\section{E. Summary and Discussion of Identification and Estimation}

The exogenous capital model given by (1)-(16) has 306 parameters, and the endogenous capital model that adds (17) has 311. Of these, 237 are in the share equation polynomials, nine are substitution parameters, and two are TFP parameters, giving 248 technology parameters in all. The occupational choice model contains 46 parameters, of which 33 are gender/educationspecific tastes for occupations. The college choice equations contain $12 \mathrm{pa}-$ rameters.

Fitting the model to the PSID data is an iterative process. Starting with a trial parameter vector, we first solve for the equilibrium of the economy in each year. Given the sequence of 29 annual equilibria, the model generates $160 \cdot 29 \cdot 2$ predicted values of type $(g, e, a)$-specific wages and labor supply to each occupation over the 29 years and 8.23 predicted college attendance rates for the eight gender/parent education types over 23 years. ${ }^{17} \mathrm{~Pa}$ rameters are updated to achieve the best fit to these 9,464 data elements via the method of moments (see online app. A).

The parameters are clearly overidentified: The model attempts to match income shares for 160 types of labor over 29 years. If share parameters varied freely across years, we could fit shares perfectly, regardless of how the substitution parameters $\rho_{s}, \rho_{u}, \rho_{H}, \rho_{L}, \rho_{u 1}, \rho_{u 2}, \rho_{e}, \rho_{g}$, and $\rho_{a}$ are set, so substitution elasticities would not be identified. But we constrain the share

\footnotetext{
${ }^{17}$ We fit college attendance rates only up through 1990 because the 1991 cohort
} does not finish school until 1997. 
parameters to lie along low-order polynomials in time, allowing identification of the substitution elasticities. Low-order polynomials provide a good fit, implying that the shares do vary slowly over time.

Furthermore, the model also attempts to match occupational employment shares for each $(g, e, a)$ kind of labor in each of the 29 years. We could fit these shares perfectly, regardless of how other model parameters are set, if group-specific tastes for each occupation (the $\left\{\alpha_{0, g, e, k}\right\}$ in eq. [10]) could vary freely over time. This would leave effects of wages on occupational choice unidentified. Instead, we constrain these occupational taste parameters to be constant over time and age. (Only tastes for home are allowed to vary by time/age; see eq. [11].)

Within this constrained structure, substitution elasticities are identified by how wages or income shares respond to variation in the supply of workers of different types over time. To gain intuition, it is useful to consider a CES production function with only two inputs, skilled labor $\left(L_{S t}\right)$ and unskilled labor $\left(L_{U t}\right)$. This generates the following equation for relative wages $\left(w_{S t} / w_{U t}\right)$ :

$$
\ln \left(w_{S t} / w_{U t}\right)=\ln \left[\lambda_{S t} /\left(1-\lambda_{S t}\right)\right]-(1-\rho) \ln \left(L_{S t} / L_{U t}\right)+\varepsilon_{t}, \quad 1-\rho<0,
$$

where the elasticity of substitution $\sigma=1 /(1-\rho)$. In our framework, technology (or demand) shocks affecting wages are captured by the $\ln \left[\lambda_{S t} /(1-\right.$ $\left.\lambda_{S t}\right)$ ] term (the ratio of CES share parameters, which captures SBTC or other demand shifts). If one can adequately control for the technology term $\ln \left[\lambda_{S t} /\left(1-\lambda_{S t}\right)\right]$, then the error $\varepsilon_{t}$ captures only error in measuring relative wages and employment using finite samples of workers. In that case one can consistently estimate $\rho$ in (18) by ordinary least squares (OLS). Otherwise, $\rho$ confounds the effect of supply-induced movements along the demand curve with shifts in demand, and one must instrument for $\ln \left(L_{S t} / L_{U t}\right)$ using exogenous labor supply shifters.

Katz and Murphy (1992) estimate a version of (18) by OLS, where $L_{S t}$ and $L_{U t}$ are college and high school labor. They assume that the SBTC term $\ln \left[\lambda_{s t} /\left(1-\lambda_{S t}\right)\right]$ follows a linear trend. (As we have noted, if shares were instead allowed to vary freely over time, then $\rho$ is not identified.) The linear trend gives a good fit to the data for 1963-87. They estimate SBTC of $3.3 \%$ per year and $\sigma=1.41$. For their estimates to be consistent, it is essential that SBTC does follow a linear trend. Given our longer period (1967-96) and finer differentiation of labor, we find that the CES share parameters must be allowed to follow third- or fourth-order time trends to provide a good fit to the data.

There remains a concern that $\varepsilon_{t}$ is contaminated by high-frequency demand shocks, in which case we should instrument for $\ln \left(L_{S t} / L_{U t}\right)$ or estimate the demand function jointly with a labor supply model. Heckman et al. (1998a, 1998b) instrument using cohort size, but we do joint estimation. 
Our supply model (i.e., the college and occupational choice equations) has several sources of exogenous variation in labor supply. ${ }^{18}$ Most notable is variation across cohorts in their size and in the distribution of gender/parental education types, denoted $\left\{N_{g, b, t-6}^{19}\right\}$ in Section II.C. Thus, while past work typically treats cohort size (and hence parent's fertility) as exogenous with respect to current demand shocks, we assume that parents' education is exogenous as well. This is equally plausible. Furthermore, parent education is a good predictor of own education and occupation.

Note that parental education rose substantially (but gradually) across cohorts (see fig. 1, dashed lines). This exogenously shifts the number of male and female college graduates in each cohort, which in turn shifts occupational choices. Substitution elasticities are identified by how such exogenous (low-frequency) supply shifts affect relative wages (or income shares). ${ }^{19}$

\section{The Data}

A. Occupational Employment Shares and Earnings

As described in equations (1) and (2), our model generates annual wages and employment for 160 types of labor, differentiated by occupation/ education/gender/age, for each year from 1968 to 1996. The wages generated by the model correspond to annual earnings of full-time-equivalent workers (FTEs). We build up the employment and wage aggregates using micro data from the core representative sample of the PSID, which began collecting data on 5,000 families in 1968 .

The procedure is as follows: First, we add up the number of FTEs in each of the 16 education/gender/age types who chose each of the 10 occupations each year. ${ }^{20}$ Then we construct aggregate earnings for each of these 160 cells by summing earnings over all PSID respondents in that cell in that year (using the PSID core sample weights). Finally, we construct the annual

${ }^{18}$ Even if our trends perfectly capture movements in $\ln \left[\lambda_{S t} /\left(1-\lambda_{S t}\right)\right]$, so $\varepsilon_{t}$ is only measurement error, it is desirable that our model contain exogenous (supply-induced) variation in $\ln \left(L_{S t} / L_{U t}\right)$. Otherwise, demand shocks would be the only source of variation in $\ln \left(L_{S t} / L_{U t}\right)$, and the two regressors in (18) would be collinear except for functional form.

${ }^{19}$ Also note that changes in current wages cannot influence current supplies of college graduates by gender/age, as these are predetermined by age 19 college choices.

${ }_{20}$ To count FTEs we must define full-time. For example, say we define a full-time professional as working 2,400 hours per year. Then a worker whose main occupation is professional and who works 1,600 hours contributes 0.75 units of labor (of his or her type) to that sector. He or she also contributes 0.25 units of time to the home sector. Thus, the number of FTEs assigned to home not only consists of workers who are unemployed or out of the labor force but also includes some fraction of the time of part-time workers. Of course, how we set full-time hours is merely a scale normalization that has no bearing on substantive results. Online app. C explains how we define full-time hours, along with some other details (e.g., how we handle workers with missing/inconsistent data on hours/earnings). 
wage for an FTE in each of the 160 cells in each year by dividing total earnings in that cell by the number of FTEs. Wages are converted to 1999 consumer price index (CPI-U) dollars.

A drawback of the PSID is that it is smaller than the Current Population Survey (CPS), leading to noisy estimates of occupational earnings and employment. But the key advantage of the PSID is the consistency of its occupational coding. Occupations are classified by 1970 census codes for the whole 1968-96 period. In contrast, the CPS changed occupational codes several times. Consistency in occupational classifications is crucial to our analysis. ${ }^{21}$

We define 10 occupations, based primarily on 1970 census one-digit codes. But in a few cases we disaggregate using three-digit codes. Most notably, we felt the Professional, Technical, and Kindred Workers category covered too wide a skill range. We split it into Professionals and Technicians using three-digit codes (see online app. B); for example, dentists are "professionals" and dental technicians are "technicians." Thus, our 10 occupations (codes in parentheses) are as follows: ${ }^{22}$

High-Skilled Occupations:

1. Professionals (selected from 001-195; see app. B)

2. Managers and Administrators (201-245)

Service Occupations (Unskilled Group 1):

3. Technicians (selected from 001-195; see app. B)

4. Sales Workers (260-285)

5. Clerical and Kindred Workers (301-395)

6. Service Workers, Except Private Household (901-965)

Blue-Collar Occupations (Unskilled Group 2):

7. Craftsmen and Kindred Workers (401-600)

8. Operatives, Except Transport (601-695)

9. Transport Equipment Operators (701-715)

10. Laborers, Except Farm (740-785)

Work hours and labor income of a PSID respondent are allocated to his or her main occupation.

${ }^{21}$ While the PSID uses 1970 census codes throughout, the level of detail varied over time. From 1968 to 1973 and 1975, only one-digit codes were recorded. In 1974, three-digit codes were recorded. Two-digit codes were recorded in 1976-80, and three-digit codes were recorded thereafter. The Retrospective Occupation-Industry Supplemental Data Files, released in 1999, used original interview descriptions of respondents' occupations to assign three-digit codes back to 1968 .

${ }^{22}$ We dropped some occupations with consistently low employment: farmers, farm laborers and supervisors, private household workers, and armed forces personnel. The self-employed with no reported occupation were also dropped. 


\section{B. College Attendance Rates}

A simplifying assumption of our model is that there are two education types, those with a high school education or less and those who attend college, regardless of whether they complete it. The use of two broad categories is similar to that in Heckman et al. (1998a, 1998b). As the sampling unit in the PSID is the household head, information on youths is often scant. Thus, rather than checking if a youth attended college at, say, ages 18-22, we can gauge attendance more accurately by looking at age 25 and seeing if he or she reports attending earlier. (This data limitation is a key motivation for our assumption that youths make educational choices at age 19 and enter the labor force 6 years later at age 25.) Even then, some PSID waves do not ask highest grade completed, so college attendance must be inferred in other ways; for example, a respondent may report finishing high school and report additional school attendance at later ages; from this we infer that he or she had some college.

We fit college attendance frequencies by cohort (from 1968 to 1990) separately by gender and parental education ( $<\mathrm{HS}, \mathrm{HS}, \mathrm{SC}$, and COL). We construct the college attendance rate for a cohort that enters at age 19 in year $t$ retrospectively by measuring the attendance rate among PSID respondents who are aged $24-26$ in year $t+6$. We use the 3 -year age window to reduce noise in the measured frequencies (by using more observations). Of course, this smooths variation in college choice frequencies over time, but we felt that this trade-off was sensible given that our model is not meant to predict very short-run movements in college attendance.

Our tuition variable is from the National Center for Education Statistics (2003, table 315) and covers in-state tuition and fees for 2- and 4-year colleges. ${ }^{23}$ This is meant to capture the average tuition level faced by those deciding on college attendance. The data are not adjusted for financial aid, nor do they include indirect costs such as room and board or commuting (note that Heckman et al.'s study shares the same limitation). We do not include data on aid because, unfortunately, such data are available only for 1987 onward (from the National Center for Education Statistics National PostSecondary Student Aid Study).

\section{Other Variables: Cohort Size, Attrition, and the Capital Stock}

Our overlapping-generations model requires as inputs (i) the age 25-64 distribution of the population by gender and education in 1968 and (ii) the cohort sizes of age 19 entrants from 1969 to 1990 (by gender and parental

${ }^{23}$ The table presents average undergraduate tuition and fees and room and board rates paid by full-time-equivalent students in degree-granting institutions for 1964-65 to 2002-3. 
background). We use census data to measure both. Thus, to arrive at our 1968 inputs, the age/education choice proportions computed using the PSID are used to divide each census age cohort into high school and college subgroups. Hazard rates from the 1970-90 US Decennial Life Tables provide attrition rates for each age group. Model inputs are not updated to account for immigration over the period. (Heckman et al. find that immigration effects are small.)

For our capital stock measure we use Bureau of Economic Analysis (BEA) estimates of nonresidential fixed investment, from tables 1.1 and 1.2 of the June 2003 National Income and Product Accounts. We add equipment and software and nonresidential structures (omitting government and residential fixed assets). More detail is provided in online appendix C.

\section{Estimation Results-Production Technology}

We fit our model to the PSID data using the method of moments (MOM). Estimation is computationally burdensome: at each trial parameter value we must solve for a 160-dimensional fixed point in each of 29 years. As our focus is on substantive results, we describe the solution algorithm and the MOM estimator in online appendix A. As noted earlier, we estimate two versions of the model, with physical capital treated as exogenous or endogenous. Interestingly, parameter estimates and model fit are very similar in each case. Thus, to conserve on space, we primarily report on the estimates and evaluation of model fit for the exogenous capital model. ${ }^{24}$

\section{A. Production Function-Elasticity of Substitution and TFP Parameters}

We begin with table 1, which reports the substitution and TFP parameters. At the highest-level CES nest (eq. [3]), we estimate that the elasticity of substitution between physical capital and skilled labor is 0.47 , while that between the capital + skilled labor aggregate and unskilled labor is 3.23. As $3.23>0.47$, we have capital-skill complementarity, consistent with the findings of Fallon and Layard (1975) and Krusell et al. (2000). Remember, however, that we define skilled labor on the basis of occupation while they define it on the basis of education.

Moving down to the next level (eq. [4]), we estimate that the skilled occupations (professionals and managers) are highly substitutable in production (i.e., $\left.\sigma_{H}=6.25\right)$. But for the two unskilled aggregates (services and bluecollar), substitution is rather inelastic $\left(\sigma_{L}=0.56\right)$. This is intuitive (e.g., it is easier to substitute an engineer for a manager than a plumber for a nurse) ${ }^{25}$

${ }^{24}$ The endogenous capital model, which has five additional parameters, also provides a slightly better fit.

${ }^{25}$ These elasticities are less precisely estimated than those in the top-level nest. This occurs for two reasons: (1) Our sources of identifying variation (i.e., changes 
Table 1

\section{CES Elasticity and TFP Parameters}

\begin{tabular}{|c|c|c|}
\hline \multirow[b]{2}{*}{ Parameter Name } & \multicolumn{2}{|c|}{ Exogenous Capital Model } \\
\hline & Estimate & SE \\
\hline$\rho_{s}:$ capital, skilled labor & -1.12 & $(.00)^{* * *}$ \\
\hline$\rho_{u}:$ capital + skilled, unskilled & .69 & $(.02)^{* * *}$ \\
\hline$\rho_{L}:$ services, blue-collar & -.78 & $(.45)$ \\
\hline$\rho_{H}:$ professionals, managers & .84 & $(1.56)$ \\
\hline$\rho_{u 1}:$ four service occupations & .14 & $(.86)$ \\
\hline$\rho_{u 2}:$ four blue-collar occupations & .04 & $(.56)$ \\
\hline$\rho_{e}:$ high school, college & .38 & $(.47)$ \\
\hline$\rho_{g}:$ male, female & .81 & $(.27)^{* * *}$ \\
\hline \multirow[t]{3}{*}{$\rho_{a}$ : four age groups } & .90 & $\cdots$ \\
\hline & \multicolumn{2}{|c|}{$\begin{array}{l}\text { Implied Elasticities of Substitution: } \\
\qquad \sigma=1 /(1-\rho)\end{array}$} \\
\hline & $\begin{array}{l}\text { Exogenous } \\
\text { Capital Model }\end{array}$ & $\begin{array}{l}\text { Endogenous } \\
\text { Capital Model }\end{array}$ \\
\hline$\sigma_{1}$ : capital, skilled labor & .47 & .41 \\
\hline$\sigma_{u}:$ capital + skilled, unskilled & 3.23 & 1.75 \\
\hline$\sigma_{L}:$ services, blue-collar & .56 & .34 \\
\hline$\sigma_{H}:$ professionals, managers & 6.25 & 9.09 \\
\hline$\sigma_{u 1}:$ four service occupations & 1.16 & 1.41 \\
\hline$\sigma_{u 2}:$ four blue-collar occupations & 1.04 & 1.25 \\
\hline$\sigma_{e}$ : high school, college & 1.61 & 1.59 \\
\hline$\sigma_{g}:$ male, female & 5.26 & 4.76 \\
\hline$\sigma_{a}:$ four age groups & 10.00 & 10.00 \\
\hline \multicolumn{3}{|l|}{ Scale and neutral technical progress: } \\
\hline$b(0)$ & 14.8 & $.0787 * *$ \\
\hline$b(1)$ & .0038 & $.0019 *$ \\
\hline
\end{tabular}

* Significant at the $5 \%$ level.

* Significant at the $1 \%$ level.

At the next level (eq. [5]), we estimate substitution elasticities among the four blue-collar occupations that form the blue-collar aggregate and for the four service occupations that form the service sector aggregate. In each case, we cannot reject that substitution is unit elastic (as $\rho_{u 1}$ and $\rho_{u 2}$ do not differ significantly from zero-either statistically or quantitatively).

The next level (eq. [6]) describes substitution between college and high school labor within occupations. We obtain 1.6, which is close to estimates

in the size and "quality" - in terms of parents' education-of entering cohorts) predict variation in skilled vs. unskilled labor aggregates better than labor supply to more narrowly defined occupations, as one would expect. (2) The estimated elasticity of substitution between professionals and managers is very high (6.25). As we will see in figs. 5 and 9, wages of managers and professionals move quite closely together. This would be true for a wide range of elasticities - as long as they are highmaking the precise elasticity both hard to pin down and, for the same reason, rather irrelevant. The same issue arises with age elasticities (see below). 
Table 2

Simulated Elasticities

\begin{tabular}{|c|c|c|c|c|}
\hline \multirow[b]{3}{*}{ Groups } & \multicolumn{4}{|c|}{ Elasticity Estimates } \\
\hline & \multicolumn{2}{|c|}{$\begin{array}{c}\text { Exogenous } \\
\text { Capital Model }\end{array}$} & \multicolumn{2}{|c|}{$\begin{array}{c}\text { Endogenous } \\
\text { Capital Model }\end{array}$} \\
\hline & Min & $\operatorname{Max}$ & Min & Max \\
\hline High school, college & 1.15 & 1.26 & 1.18 & 1.30 \\
\hline Male, female & 1.85 & 2.20 & 2.02 & 2.20 \\
\hline Skilled, unskilled occupations & .72 & 1.09 & 1.09 & 1.26 \\
\hline
\end{tabular}

in the prior literature (which, as Heckman et al. note, are centered on 1.4-1.5). However, our figure is not directly comparable to those in the prior literature, which has not differentiated labor by both education and occupation. In order to obtain the elasticity between total college labor and total high school labor (as opposed to within-occupation), we must simulate an exogenous increase in the supply of college labor. ${ }^{26}$

As we note in table 2, simulations of our model imply substitution elasticities for high school and college labor in the range of 1.15-1.26. ${ }^{27}$ This is well below the elasticity of 1.6 we obtained for high school and college labor within a one-digit occupation, but it is still well within the range of the prior literature (e.g., Heckman et al. obtain 1.26 when they instrument for the college/high school labor supply ratio using cohort sizes). It is intuitive that different education levels are more easily substitutable within occupations (e.g., a high school-educated manager could more easily substitute for a college-educated manager than a high school-educated laborer could).

The next-lower nest (eq. [7]) describes substitution between males and females (within education and occupation cells). We estimate that this elasticity is very high (5.26). Thus, male and female workers appear to have very similar skills, conditional on education/occupation. On the other hand, we can also simulate the elasticity of substitution between total male and female workers. As we see in table 2, when we do this, the range of elasticities is 1.85-2.20. Thus, not surprisingly, male and female workers appear much less similar unconditionally.

At the bottom level (eq. [8]), we estimate substitution among age groups conditional on the gender/education/occupation cell. Our estimates of this elasticity were very high, and the algorithm had a hard time pinning down a

${ }^{26}$ That is, we simulate a "helicopter drop" of college workers, increasing the number of such workers at each age by the same proportion. These new workers choose occupations in the same way that workers do normally in the model.

${ }^{27}$ The elasticity of substitution between two inputs that appear in a second- or lower-level nest depends on the share parameters in all common higher nests. As these share parameters vary over time, so will the substitution elasticities. Thus, for inputs such as high school and college labor, we cannot give a single elasticity figure but a range of figures. 
final value. So we decided to peg it at 10 . This gives unconditional elasticities in the 4-4.5 range, comparable to Card and Lemieux (2001).

Finally, the estimate of $b(1)$ implies TFP growth of $0.4 \%$ per year (the BEA estimates TFP growth over the $1968-96$ period of $0.55 \%$ per year). ${ }^{28}$ Remaining output growth is due to growth of capital and labor and growth in labor quality via educational/occupational upgrading.

\section{B. Production Function-CES Share/Productivity Parameters}

As noted in Section II.A, we let the share parameters vary over time according to cubic or quartic trends. There are 237 polynomial parameters. Given this large number and the fact that polynomial coefficients are very hard to interpret, we relegate them to online appendix D. Instead, table 3 reports the implied values of the CES share parameters for three selected years: 1968, 1982, and 1992 (the beginning, middle, and end of our sample). Of course, to the extent that CES substitution parameters depart from zero (i.e., from Cobb-Douglas), the "share" parameters are not exactly equal to income shares. However, their trends over time tell us how demands for (and income shares of) the various groups move. Some interesting patterns emerge from the estimates:

First, as we see in panel A of table 3, while the share of the capital + skilled labor composite rises from 1968 to 1982, it falls back to its original level by 1996. And the skilled labor share within the capital + skilled labor composite falls slightly. Thus, a general increase in the return to skill does not explain the rise of the college premium over this period. This is consistent with papers by Card and DiNardo (2002) and Eckstein and Nagypal (2004), who argue that a simple trend in the share of skilled labor cannot explain changes in the wage structure over the 1970s-90s.

Second, the share of the service occupations (relative to blue-collar) rises substantially. This implies increased demand for female labor, as women are more likely to choose that sector.

Third, in panel B of table 3, which reports the shares of high school versus college workers within occupations, we see that the high school share falls substantially in six of the 10 occupations: managers, sales workers, service workers, craft workers, operatives, and laborers. It falls more modestly for professionals and technicians. (Only for clerical workers and transport operatives does it stay flat.) Thus, a shift in demand toward college labor is clearly a key factor (along with capital-skill complementarity) in explaining the rise of the college wage premium.

Fourth, in panel C of table 3, which reports gender shares, we see that the share of high school males (relative to high school females) falls in all 10

${ }^{28}$ See "Multifactor Productivity Trends, 1997" (http://www.bls.gov/schedule /archives/all_nr.htm\#PROD3). We may obtain a smaller estimate of TFP growth because our model better captures skill upgrading of the labor force. 
Table 3

\section{CES Share Parameter Estimates: Selected Years}

$1968 \quad 1982 \quad 1996$

A. Skill and occupational shares:

(Capital + skilled labor) aggregate: $\lambda_{s}$

Capital in (capital, skilled labor) aggregate: $\lambda_{A}$

$\begin{array}{lll} & & \\ .261 & .374 & .262 \\ .846 & .969 & .902 \\ & & \\ .297 & .434 & .614 \\ .462 & .435 & .466 \\ & & \\ .248 & .324 & .363 \\ .195 & .180 & .195 \\ .355 & .320 & .271 \\ & & \\ .493 & .538 & .534 \\ .317 & .246 & .243 \\ .115 & .136 & .150 \\ & & \\ .188 & .161 & .165 \\ .396 & .360 & .294 \\ .297 & .249 & .233 \\ .460 & .323 & .296 \\ .576 & .553 & .576 \\ .728 & .580 & .502 \\ .767 & .672 & .626 \\ .912 & .777 & .742 \\ .716 & .754 & .721 \\ .826 & .735 & .558\end{array}$

Snskilled and skill labor aggregates, share of:

Professionals: $\lambda_{1}$

Services aggregate, share of:

Technicians: $\lambda_{3}$

Sales: $\lambda_{4}$

Clerical: $\lambda_{5}$

Blue-collar aggregate, share of:

Craft workers: $\lambda_{7}$

Operatives: $\lambda_{8}$

Transport operatives: $\lambda_{9}$

B. Education shares by occupation: high school share among:

Professionals: $\mu_{1}$

Managers: $\mu_{2}$

Technicians: $\mu_{3}$

Sales workers: $\mu_{4}$

Clerical workers: $\mu_{5}$

Service workers: $\mu_{6}$

Craft workers: $\mu_{7}$

Operatives: $\mu_{8}$

Transport operatives: $\mu_{9}$

Laborers: $\mu_{10}$

.826

$.735 \quad .558$

C. Gender shares by education/occupation:

High school male share of high school labor aggregate among:

Professionals: $\xi_{1}$

Managers: $\xi_{2}$

$.616 \quad .677 \quad .568$

Technicians: $\xi_{3}$

Sales workers: $\xi_{4}$

$\begin{array}{lll}.763 & .767 \quad .683\end{array}$

Clerical workers: $\xi_{5}$

$\begin{array}{lll}.596 & .568 \quad .544\end{array}$

Service workers: $\xi_{6}$

Craft workers: $\xi_{7}$

Operatives: $\xi_{8}$

$\begin{array}{lll}.699 & .669 & .637\end{array}$

Transport operatives: $\xi_{9}$

$\begin{array}{lll}.897 & .809 & .778\end{array}$

Laborers: $\xi_{10}$

$\begin{array}{lll}.782 & .734 \quad .602\end{array}$

College male share of college labor aggregate among:

Professionals: $\gamma_{1}$

Managers: $\gamma_{2}$

$.754 \quad .725 \quad .642$

Technicians: $\gamma_{3}$

Sales workers: $\gamma_{4}$

$\begin{array}{lll}.650 & .594 & .574\end{array}$

Clerical workers: $\gamma_{5}$

$.960 \quad .754 \quad .651$

Service workers: $\gamma_{6}$

$\begin{array}{lll}.631 & .603 & .563\end{array}$

Craft workers: $\gamma_{7}$

$\begin{array}{lll}.688 & .700 \quad .719\end{array}$

Operatives: $\gamma_{8}$

$\begin{array}{lll}.778 & .753 & .783\end{array}$

Transport operatives: $\gamma_{9}$

$\begin{array}{lll}.457 & .668 & .749\end{array}$

Laborers: $\gamma_{10}$

$\begin{array}{lll}.717 & .803 & .787\end{array}$

$.507 \quad .710 \quad .473$ 
D. Age group shares by gender/education/occupation: Age group shares of high school male aggregate, skilled occupations: $\tau_{1-2}$ :

Age 25-34

Age 35-44

.225

Age 45-54

.278

Age group shares of high school male aggregate, service

.267

$.279 \quad .277$

occupations: $\tau_{3-6}$ :

Age 25-34

$\begin{array}{lll}.252 & .241 & .248\end{array}$

Age 35-44

$\begin{array}{lll}.270 & .256 & .279\end{array}$

Age 45-54

$\begin{array}{lll}.258 & .270 \quad .268\end{array}$

Age group shares of high school male aggregate, blue-collar occupations: $\tau_{7-10}$

Age 25-34

Age 35-44

$\begin{array}{lll}.274 & .259 & .283\end{array}$

Age 45-54

.260

$.271 \quad .269$

Age group shares of high school female aggregate, skilled occupations: $\sigma_{1-2}$ :

Age 25-34

.221

.244

.235

Age 35-44

Age 45-54

.254

$.245 \quad .282$

Age group shares of high school female aggregate, service occupations: $\sigma_{3-6}$ :

Age 25-34

Age 35-44

Age group shares of high school female aggregate, blue-collar

$.245 \quad .283$
occupations: $\sigma_{7-10}$ :

Age 25-34

Age 35-44

Age 45-54

Age group shares of college male aggregate, skilled occupations: $\nu_{1-2}$ :

Age 25-34

.221

$.217 \quad .235$

Age 35-44

Age 45-54

.282

$.271 \quad .289$

Age group shares of college male aggregate, service occupations: $\nu_{3-6}$ :

Age 25-34

Age 35-44

$.288 \quad .260 \quad .260$

Age 45-54

$.282 \quad .271 \quad .288$

Age group shares of college male aggregate, blue-collar occupations: $\nu_{7-10}$ :

Age 25-34

Age 35-44

Age 45-54

Age group shares of college female aggregate, skilled occupations: $\varpi_{1-2}$ :

Age 25-34

Age 35-44

$\begin{array}{lll}.220 & .277 \quad .249\end{array}$

Age 45-54

$.298 \quad .233 \quad .270$


Table 3 (Continued)

\begin{tabular}{llll}
\hline & 1968 & 1982 & 1996 \\
\hline Age group shares of college female aggregate, service & & & \\
$\quad$ occupations: $\varpi_{3-6}$ : & & & \\
Age 25-34 & .238 & .254 & .257 \\
Age 35-44 & .212 & .268 & .240 \\
Age 45-54 & .315 & .248 & .286 \\
Age group shares of college female aggregate, blue-collar & & & \\
$\quad$ occupations: $\varpi_{7-10}$ : & & & \\
Age 25-34 & .227 & .243 & .247 \\
Age 35-44 & .192 & .243 & .219 \\
Age 45-54 & .287 & .227 & .263 \\
\hline
\end{tabular}

NOTE.-Three gender/education/occupation cells were dropped because of extremely small cell counts: female (college and high school) transport operatives and college female laborers.

occupations. The college male share falls in eight out of 10 . Together, the second and fourth patterns-growing demand for labor in the service sector and demand shifts toward female labor within most occupationscan explain both (i) closing gender wage and employment gaps and (ii) the fact that high school females fared much better than high school males over the 1969-96 period.

Finally, panel D of table 3 reports age group shares. These are very stable, but there is a weak upward trend for the younger age group (25-34) among all females and college males.

\section{The Occupational Choice Equation}

Table 4 reports on the occupational choice equation. The coefficient $\alpha_{1}$ on the annual wage is .0000862 . This implies a labor supply elasticity to a single occupation of about 4-6 and to the economy as a whole of roughly 0.74 for both high school and college males (the equality is a coincidence) and 1.13 and 0.94 for college and high school females, respectively. Details of these calculations are provided in online appendix E. These elasticities are important for how the model explains changes in the wage structure: they influence the extent to which wage increases in a sector or occupation are "choked off" by increased labor supply.

Next, the estimate of $\alpha_{2}$ implies that workers get a psychic benefit from working in an occupation in which other workers have education similar to their own. And the estimate of $\alpha_{3}$ implies the existence of mobility costs. As a result, the increase in labor supply to an occupation resulting from increased labor demand will not be fully realized within one period.

The next panel of table 4 reports the nonpecuniary costs/payoffs $\left(\alpha_{0, g, e, k}\right)$ from working in each occupation for each of the four gender/education types. These fall into predictable patterns. For instance, women (whether high school or college educated) have a preference for clerical and service (i.e., "pink-collar") occupations and a relative distaste for being laborers. 
Panel B of table 4 reports parameters related to the value of home time. As expected, females have a positive intercept shift $\left(\alpha_{b 0, f}=2.02\right)$, so they have a higher value of home time than males. But they also have a negative time trend $\left(\alpha_{b 1 ; f}=-.028\right)$. Thus, a declining value of home time (presumably due to declining fertility) explains part of the increase in female labor supply over this period. Of course, part is also due to increased demand for female labor (see Sec. IV.B).

Notably, the occupational choice model (10)-(11) treats the home sector symmetrically with the various market sectors (occupations). Hence, the extent to which women shift among occupations in response to shifts in occupational wages constrains the extent to which we can attribute changes in their labor force participation to changes in wages. This helps to identify the part of the change in participation attributable to a changing value of home time.

Finally, the table reports the gender/age effects in the value of home time $\left(\alpha_{g, a}\right.$ in [11]). As expected, these are increasing with age. This is in part how the model explains retirement.

\section{The College Choice Equation-Explaining the "Stagnating" Supply of College Labor}

Before we discuss estimates of the college choice equation, it is useful to examine trends in college attendance over the sample period. Figure 1 (top panel) shows college attendance by cohort for males and females. For males, the attendance rate was high for the cohort deciding on college in the late 1960s and entering the labor market in the early to mid-1970s. But it declines quickly over the next several years and then stays fairly flat in the 1980s and 1990s (despite the rising college premium). For females, attendance is flat over the whole period. The model provides a good fit to this pattern of a "stagnant" supply of college labor despite rising college wage premia.

The bottom panels of figure 1 show that the model continues to provide a good fit when the data are broken down by gender/parental education; for example, the attendance rate for males with high school graduate parents falls from over $60 \%$ in the late 1960 s to less than $30 \%$ in 1990 , and the model captures this dramatic downward trend well. How does the model explain such patterns?

To answer this question, we first calculate, for each cohort of 19-yearolds from 1968 to 1996, the expectation, at the time of their college choice, of the present value of lifetime income for college versus high school workers. This is done using the wage structure at the time of the choice, along with equation (12), which gives occupation and home choice probabilities, and with $\delta=.95$. For males, we find that the (perceived) college lifetime earnings premium was about $\$ 415,000$ for the 1968 cohort, narrowed to $\$ 330,000$ in the $1974-83$ period, widened to $\$ 400,000$ in 1990 , and wid- 
Table 4

Occupational Choice

A. Values of Occupations

\begin{tabular}{|c|c|c|c|c|}
\hline Parameter Name & Estimate & SE & & \\
\hline \multirow{6}{*}{$\begin{array}{l}\text { Annual earnings: } \alpha_{1} \\
\text { Education difference: } \alpha_{2} \\
\text { Lagged occupational choice } \\
\text { probability: } \alpha_{3}\end{array}$} & $8.62 \mathrm{E}-05$ & $(2.67 \mathrm{E}-05)^{*}$ & & \\
\hline & 1.24 & $(.49)^{*}$ & & \\
\hline & 1.41 & $(.42)^{* * *}$ & & \\
\hline & \multicolumn{4}{|c|}{$\begin{array}{l}\text { Nonpecuniary Payoffs from Occupations, by } \\
\text { Gender/Education Group (Net of } \alpha_{2} \text { Effect): } \\
\alpha_{0, g, e, k}, g=\mathrm{M}, \mathrm{F}, e=\mathrm{HS} \text {, COL, } k=1,10\end{array}$} \\
\hline & \multicolumn{2}{|c|}{ Males } & \multicolumn{2}{|c|}{ Females } \\
\hline & Estimate & SE & Estimate & SE \\
\hline \multicolumn{5}{|l|}{ High school graduates: } \\
\hline 1. Professionals & -1.65 & $(.07)^{* * *}$ & -1.31 & $(.33)^{* * *}$ \\
\hline 2. Managers & .15 & $(.18)$ & 1.01 & $(.21)^{* * * *}$ \\
\hline 3. Technicians & -.80 & $(.07)^{* * *}$ & .50 & $(.35)$ \\
\hline 4. Sales & -.55 & $(.02) * *$ & 1.04 & $(.48)^{* *}$ \\
\hline 5. Clerical & -.24 & $(.01)^{* * *}$ & 2.23 & $(.25)^{* * *}$ \\
\hline 6. Service & .84 & $(.20) * * *$ & 2.50 & $(.40) * * 2$ \\
\hline 7. Craft & 1.21 & & -.27 & \\
\hline 8. Operatives & .97 & $(.04)^{* * *}$ & 1.76 & $(.24)^{* * *}$ \\
\hline 9. Transport operatives & .44 & $(.00) * * *$ & $-\infty$ & \\
\hline 10. Laborers & .73 & $(.20)^{* * *}$ & -2.08 & $(.27)^{* * *}$ \\
\hline \multicolumn{5}{|l|}{ College graduates: } \\
\hline 1. Professionals & -.94 & $(.80)$ & -.12 & $(.27)$ \\
\hline 2. Managers & -.82 & $(.78)$ & .33 & $(.15)^{*}$ \\
\hline 3. Technicians & -.15 & $(.43)$ & 1.49 & $(.06) * *$ \\
\hline 4. Sales & -.95 & $(.56)$ & .17 & $(.10)$ \\
\hline 5. Clerical & .17 & $(.06)^{* * *}$ & 2.62 & $(.36)^{* * *}$ \\
\hline 6. Service & .22 & $(.04)^{* * *}$ & 2.05 & $(.53)^{* * *}$ \\
\hline 7. Craft & .89 & & -.77 & \\
\hline 8. Operatives & -.42 & $(.18)^{*}$ & .32 & $(.52)$ \\
\hline 9. Transport operatives & -.42 & $(.15)^{* * *}$ & $-\infty$ & \\
\hline 10. Laborers & -.46 & $(.30)$ & $-\infty$ & \\
\hline
\end{tabular}

B. Value of Outside Option (Home)

\begin{tabular}{lcl}
\hline & Estimate & SE \\
\hline Constant: $\alpha_{b 0}$ & 3.29 & $(.66)^{* * *}$ \\
Time trend: $\alpha_{b 1}$ & .0174 & $(.0046)^{* * *}$ \\
Female constant shift: $\alpha_{b 0 . f}$ & 2.02 & $(.03)^{* * *}$ \\
Female trend shift: $\alpha_{b 1, f}$ & -.0283 & $(.0048)^{* * *}$
\end{tabular}


Table 4 (Continued)

\begin{tabular}{|c|c|c|c|c|}
\hline \multirow[b]{3}{*}{ Age Range } & \multicolumn{4}{|c|}{ Age Effects on Value of Outside Option (by Gender): $\alpha_{g, a}$} \\
\hline & \multicolumn{2}{|c|}{ Males } & \multicolumn{2}{|c|}{ Females } \\
\hline & Estimate & SE & Estimate & SE \\
\hline $25-34$ & .00 & & -.01 & $(.06)$ \\
\hline $35-44$ & .59 & $(.29)^{*}$ & .00 & \\
\hline $45-54$ & 1.28 & $(.37)^{* * *}$ & .13 & $(.02) * *$ \\
\hline $55-64$ & 1.85 & $(.25)^{* * *}$ & .73 & $(.03) \div *$ \\
\hline
\end{tabular}

ened further to $\$ 480,000$ in 1996 . Online figure F1 presents these results graphically.

Next, table 5 reports our estimates of the college choice equation. The coefficient on the expected present value of lifetime income governs how the college premium affects college attendance. For males, the coefficient $\phi_{1 m}$ is .0000134 . This implies an elasticity of supply of college labor with respect to the gain to college of about 3.2. ${ }^{29}$ This elasticity is important for how the model explains changes in the wage structure. It governs how quickly an increased college premium is "choked off" by increased supply of college labor.

The time trend in male tastes for college is small, implying that tastes were nearly the same in the 1990 s as in 1968. This is important: the model can explain the puzzle of stagnating male college attendance (despite a rising college wage premium) without resort to declining tastes for college. The key is the 6-9-point increase in the home share for males discussed below (Sec. VII). This counteracts the increasing college wage premium, so the lifetime earnings premium actually falls from $\$ 415,000$ in 1968 to $\$ 400,000$ in 1990 (as noted earlier). With an elasticity of 3.2, this implies a 12\% drop in college attendance - about what we see in the data.

For women the situation is reversed. Their college attendance rate fluctuates around $45 \%$ throughout the period (see fig. 1), despite (i) increased demand for female labor (see Sec. IV.B) and (ii) a downward trend in returns to the nonmarket alternative (see Sec. V). These factors caused the lifetime income gain from college for women to more than double, from $\$ 85,000$ in 1968 to $\$ 200,000$ in 1990 (see fig. F1). Thus, to explain why atten-

${ }^{29}$ For example, as we see in fig. F1, in the 1990 cohort, expected present values of lifetime income for male college and high school workers were $\$ 930,000$ and $\$ 530,000$, respectively, a $\$ 400,000$ difference. In fig. 1 , we see that the college attendance rate in this cohort was roughly $42 \%$. Say the gain to college increased by $10 \%$, or $\$ 40,000$. This increases the latent index for college (eq. [13]) by .54, increasing attendance to $55.4 \%$, a $32 \%$ increase. Thus we get an elasticity of $32 / 10=3.2$. 
Table 5

Educational Choice

\begin{tabular}{lll}
\hline Parameter Name & Estimate & \multicolumn{1}{c}{$\mathrm{SE}$} \\
\hline Present value of lifetime earnings (males): $\phi_{1 m}$ & $1.34 \mathrm{E}-05$ & $(3.07 \mathrm{E}-06)^{* * *}$ \\
Present value of lifetime earnings (females): $\phi_{1 f}$ & $6.41 \mathrm{E}-06$ & $(1.30 \mathrm{E}-07)^{* * *}$ \\
Cost of college, by parental background type: $\phi_{2 b}:$ & & \\
$\quad<$ High school parents & 6.04 & $(1.96)^{* * *}$ \\
High school parents & 4.87 & $(1.95)^{* *}$ \\
Some college parents & 3.82 & $(1.95)$ \\
College parents & 2.90 & $(1.95)$ \\
Female intercept shift: $\phi_{3}$ & 4.12 & $(1.38)^{* * *}$ \\
Calendar time effects: & & \\
Female time trend: $\phi_{4}$ & $1.29 \mathrm{E}-02$ & $(2.47 \mathrm{E}-02)$ \\
Female trend squared: $\phi_{5}$ & $-6.84 \mathrm{E}-03$ & $(5.48 \mathrm{E}-04)^{* * *}$ \\
Male time trend: $\phi_{6}$ & $9.80 \mathrm{E}-02$ & $(1.23 \mathrm{E}-01)$ \\
Male trend squared: $\phi_{7}$ & $-3.34 \mathrm{E}-03$ & $(1.29 \mathrm{E}-03)^{* *}$ \\
Tuition cost: $\phi_{8}$ & $3.53 \mathrm{E}-05$ & $(1.76 \mathrm{E}-04)$ \\
\hline
\end{tabular}

NOTE.-The "cost of college" (by parental background type) potentially includes both monetary and nonmonetary costs, while the tuition cost is just one component of the monetary cost.

* Significant at the $5 \%$ level.

$\approx$ Significant at the $1 \%$ level.

dance did not increase, the nonmarket return from college must have fallen. This is what the trend coefficients in table 5 imply. Plausibly, this reflects reduced importance of marriage market returns to college.

The coefficient on lifetime income for women, $\phi_{1 f}$, is half that for men. This is consistent with results in Keane and Wolpin (2010) that half of women's gain to college comes from better marriage market opportunities rather than from higher earnings. Affirming this, the present-value-ofincome gains for women are half that of men (see fig. F1), yet their attendance rate is similar. Women must get more utility from college or reap gains via a different channel (i.e., the marriage market). As we do not model marriage, the model says that women get more utility from college $\left(\phi_{3}=4.12\right)$.

Besides capturing the downward trends in college attendance for all eight gender/parent education types, the model also captures level differences quite well. These level differences are substantial (see fig. 1). For instance, for males with parent types $<\mathrm{HS}$, HS, SC, and COL, college attendance rates in 1990 were $12.6 \%, 28.7 \%, 52.2 \%$, and $72 \%$. Note that it is not a foregone conclusion that the model would capture both level differences and time trends for all eight gender/parent-education types, as it has no gender/parent-education/time interactions. ${ }^{30}$

As expected, the fixed effects for parental education figure prominently in the cost of college. For example, using the male coefficient on earnings to

${ }^{30}$ Notice that, in fig. 1, college attendance rates trend down for females of all four parental education types. Yet we also see that the college attendance rate for all females stayed flat, at roughly $45 \%$ because average education levels of parents rose substantially across these cohorts (as is shown in the dotted lines in fig. 1). 
translate to monetary equivalents, the cost of college is greater by $(4.87-$ $3.82) / .0000134=\$ 78,000$ for youths whose parents were high school graduates versus those whose parents had some college. ${ }^{31}$ The magnitude of these costs is large relative to average tuition levels. Thus, the most plausible interpretation is that they primarily capture psychic/effort costs. Finally, the effect of tuition is found to be small and insignificant. But as we noted in Section III, tuition is a rather poor measure of true college costs.

\section{Evaluation of Model Fit to Wage and Employment Patterns}

In this section we evaluate the fit of the model to patterns of occupational wages and employment shares in the PSID data. Of course, the PSID data fluctuate from year to year because of the relatively small sample size, which generates noise in population aggregates. Thus, our hope is that the model will fit the broad trends in the data. The aggregate results (i.e., for all workers) are plotted in online figures F2-F4.

In general, the model appears to do quite well. For instance, it captures the roughly 10-point drop in the home share from 1968 to 1996 quite accurately (see fig. F4). Other key patterns are that employment shares of professionals, managers, and technicians increased substantially, while sales and services were flat (see fig. F2). Thus, most of the growth of the broad service sector was from technicians and clerical workers. The shares of all four blue-collar occupations fell. The model captures all these patterns well, except it understates the growth in clerical workers somewhat. Figure F3 shows that the model also fits occupational wages well-both time trends within occupations and level differences across occupations.

It is perhaps more interesting and important to evaluate the fit of the model to the various demographic subgroups. Thus, figures $2-9$ assess the fit to occupation shares and earnings for each of the four gender/education groups (note that only results for occupations with at least a $2 \%$ share are reported for each group), while figure F4 reports the fit to the home shares. Given the complexity of the patterns, the fit is surprisingly good.

For high school males, two aspects of the data are notable. First, the home sector share rises from $15 \%$ to $24 \%$ during the period (see fig. F4). Second, in about 1974 wages start to trend down in all four blue-collar occupations (see fig. 3). The model captures these wage trends well, and it gets the magnitude of the increase in home about right (i.e., $8 \%$ predicted vs. $9 \%$ data). The occupation with the largest employment share decline is operatives, falling from $16 \%$ in 1968 to $10 \%$ in 1996, a pattern the model captures almost perfectly (see fig. 2).

For college males, the home share goes from 9\% in 1968 to $15 \%$ in 1996 (see fig. F4). This is nearly as large as the increase for high school males.

\footnotetext{
${ }^{31}$ Similarly, Heckman et al. obtain a large range of $\$ 99,000$ in the cost to college across their four AFQT types.
} 


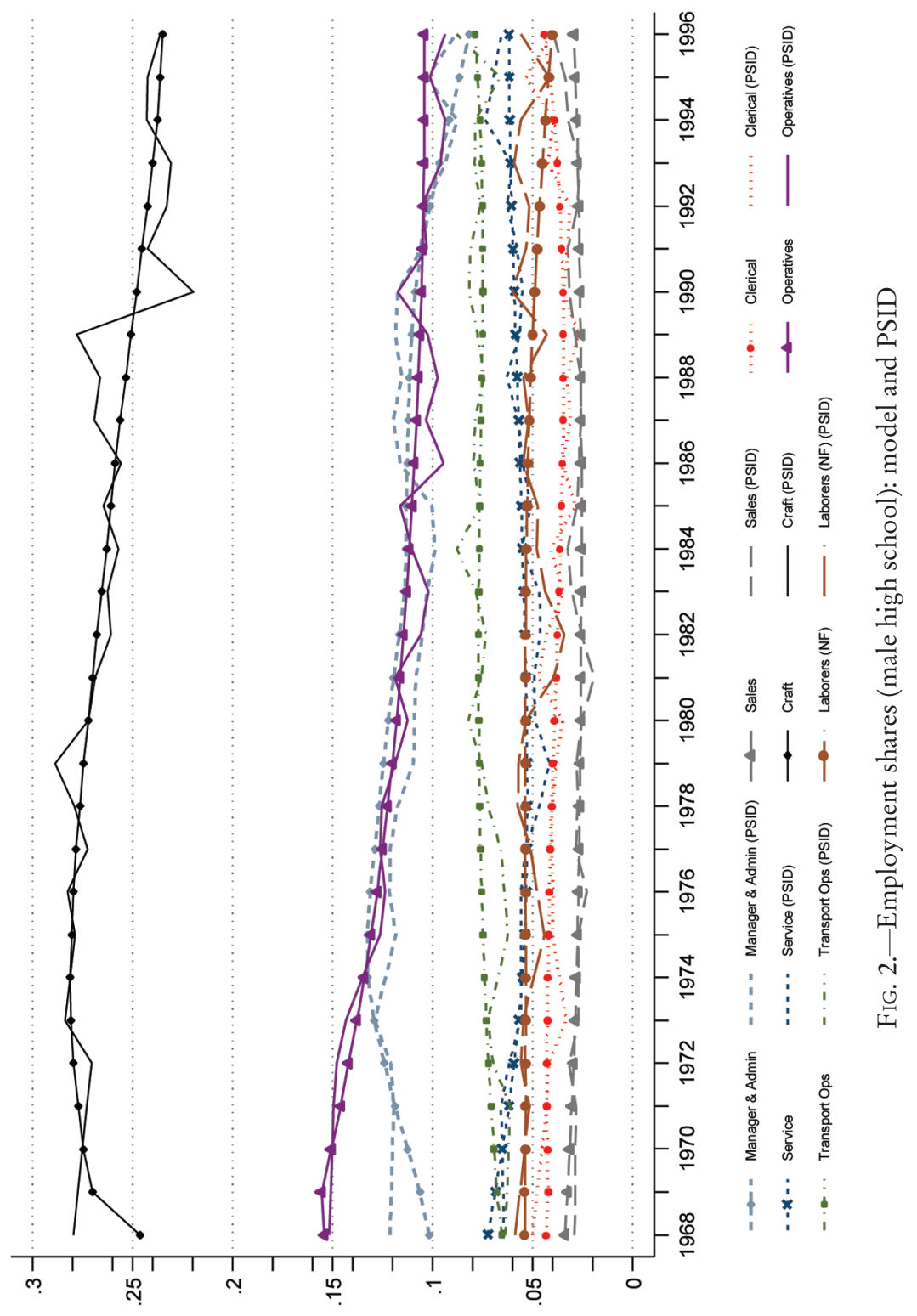




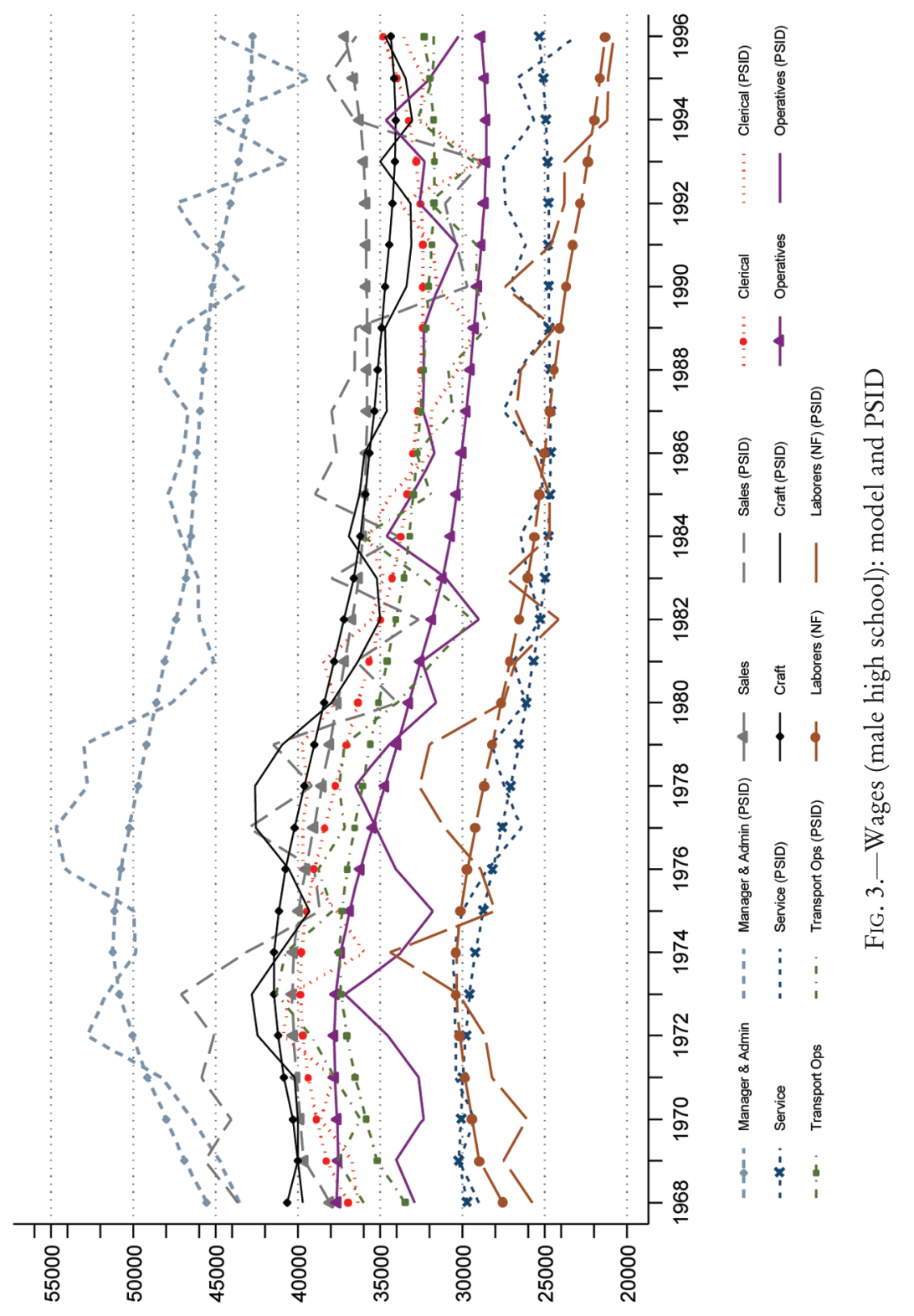


Employment shares drop substantially in professional and clerical occupations, while other occupations are fairly stable (see fig. 4). The model captures these patterns well. Of course, the largest occupations for college males are managers and professionals, followed by technicians. In all three, there is a clear downward trend in wages for the first half of the sample period and an upward trend in the second half, with the break point happening in about 1982-83 (see fig. 5). By 1996, real wages for college males in these occupations are roughly back where they started in 1968. Thus, for males, the growth in the college wage premium over the period as a whole is clearly due to declining high school wages. Only in the post-1982 period do growing college wages contribute to the trend. Beaudry and Green (2005) emphasize the importance of this pattern, which our model generates.

Next we turn to high school females. In contrast to males, the home share falls sharply, from about $69 \%$ in 1968 to $47 \%$ in 1996 (see fig. F4). The model predicts a decline from $63 \%$ to $47 \%$. Thus, it captures the trend well but overstates home in the early years. As we see in figure 6, the occupations in which employment increases most are clerical (9\% to 19\%) and managers $(2 \%$ to $7 \%)$. The model overstates clerical's share in the early years by about 4 points (the flip side of understating home). But it captures the broad upward trend in the clerical sector.

Occupational earnings paths of high school females diverge sharply from those of high school males (see fig. 7). In almost every occupation they have at least a mild upward trend in wages over the 1968-96 period. In particular, the three largest occupations for high school females are clerical (19\% in 1996), services (10\% in 1996), and managers (7\% in 1996). In all three, wages trended upward. The third-largest is operatives (6\% in 1996), where wages were quite flat. Indeed, high school female wages were flat or mildly increasing in all blue-collar occupations. But for high school males, wages fell in all these occupations. Differences are sometimes substantial: for example, for operatives, wages of high school males fell about $20 \%$ while those of females were flat; for managers, wages of high school males fell $8 \%$ while those of females doubled. It is difficult to reconcile a view that the rising college premium represents simply a general increase in returns to skill-or that males and females are perfect substitutes in production-when high school females did so well relative to high school males. ${ }^{32}$ Eckstein and Nagypal (2004) emphasize this pattern, which our model fits successfully.

\footnotetext{
${ }^{32}$ Part of the relative growth of female wages within education/occupation cells may be due to skill upgrading via increased work experience. Given the increase in female employment rates and consensus estimates of experience returns, we calculate that this mechanism is unlikely to raise relative wages of prime working age women by any more than $5 \%$. Thus, this mechanism seems unable to explain differences of the magnitude we see here.
} 


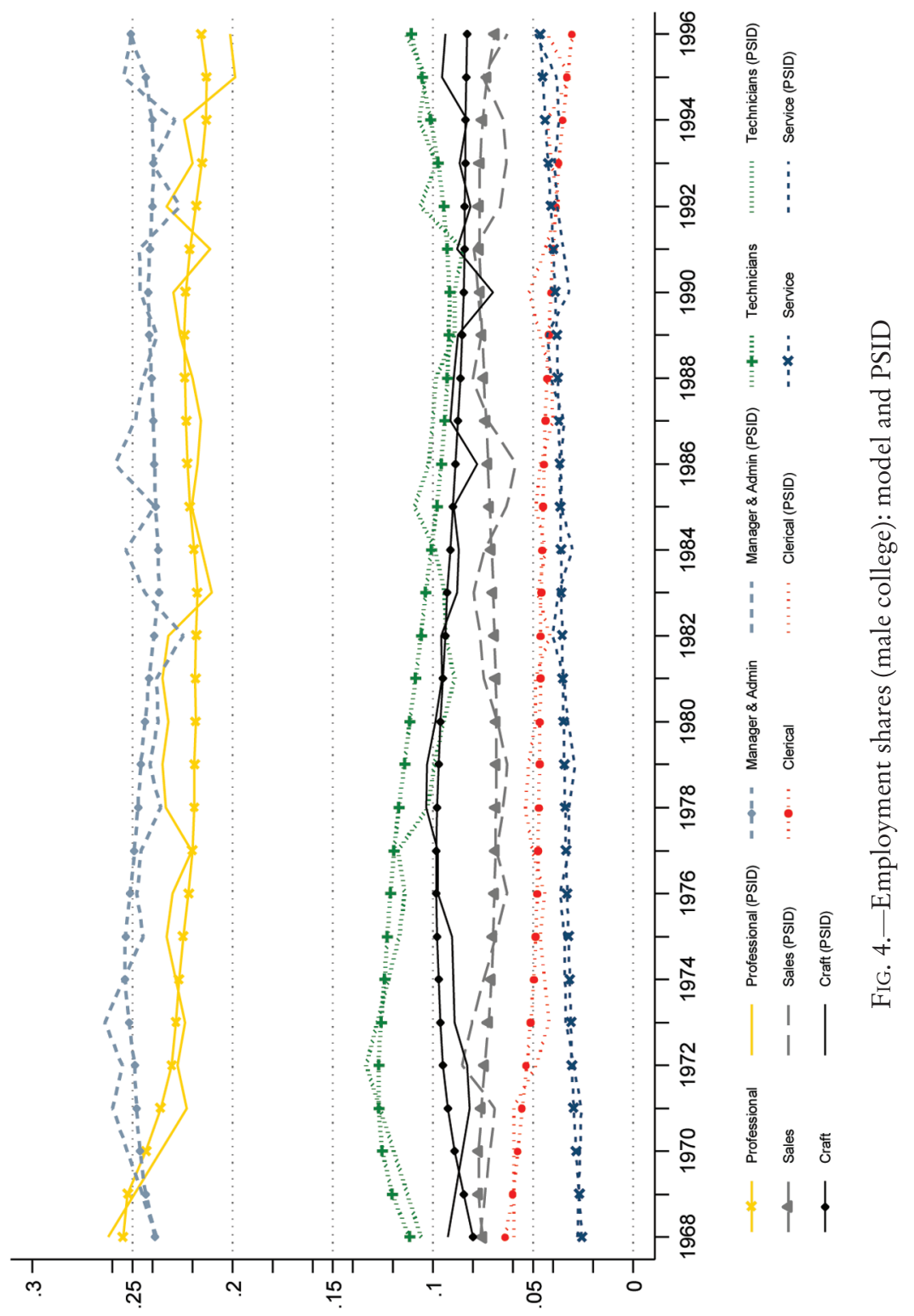




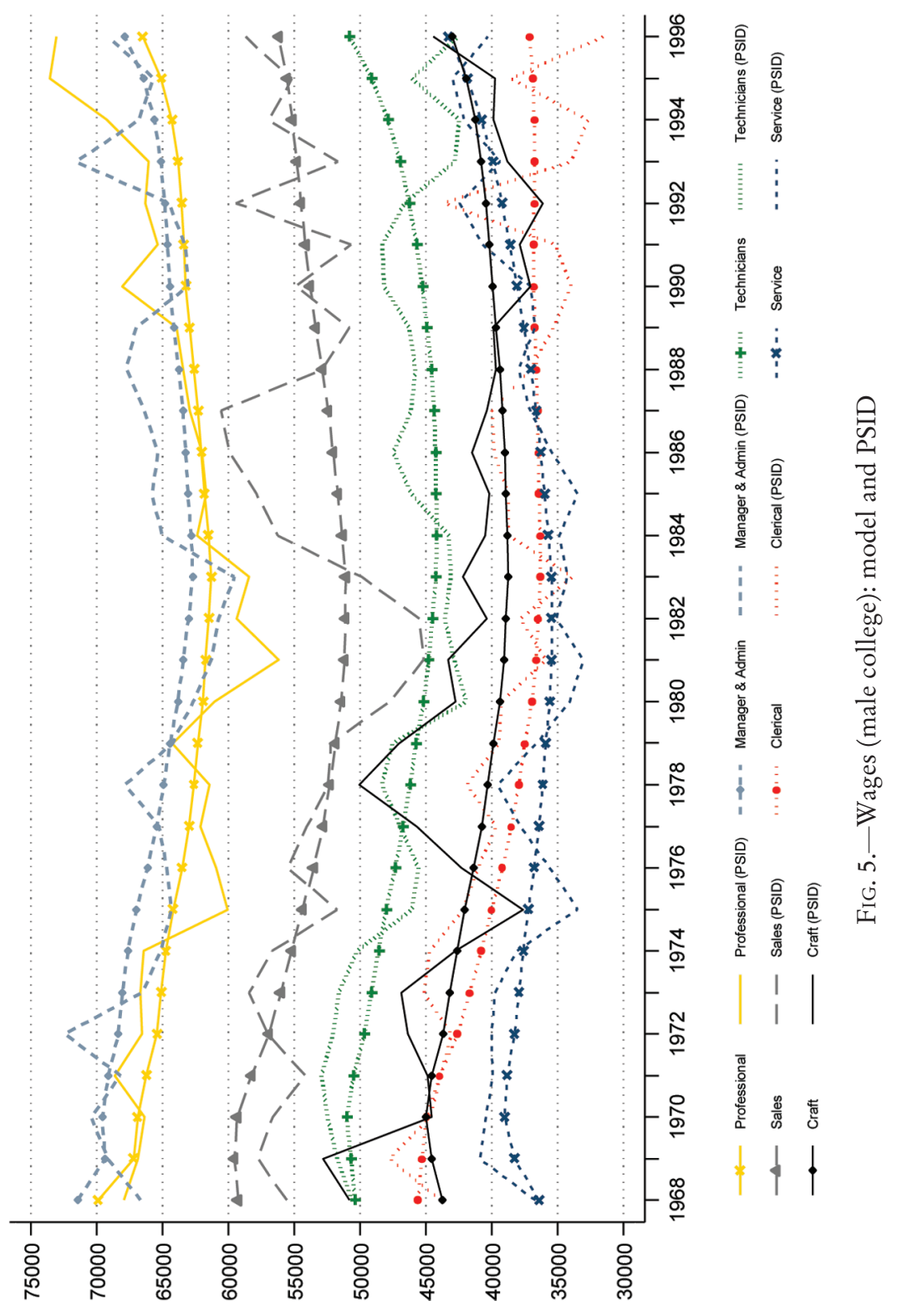




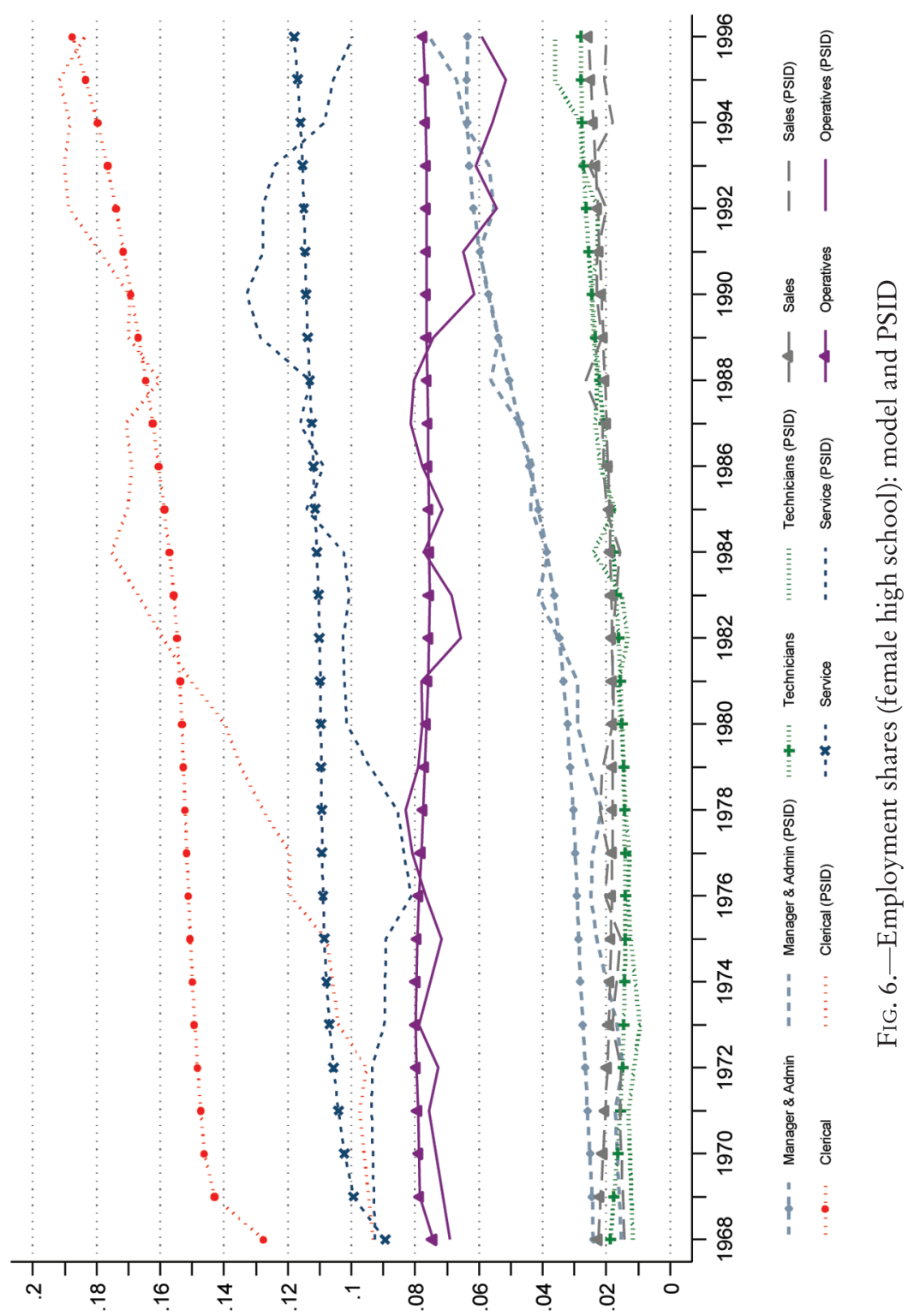




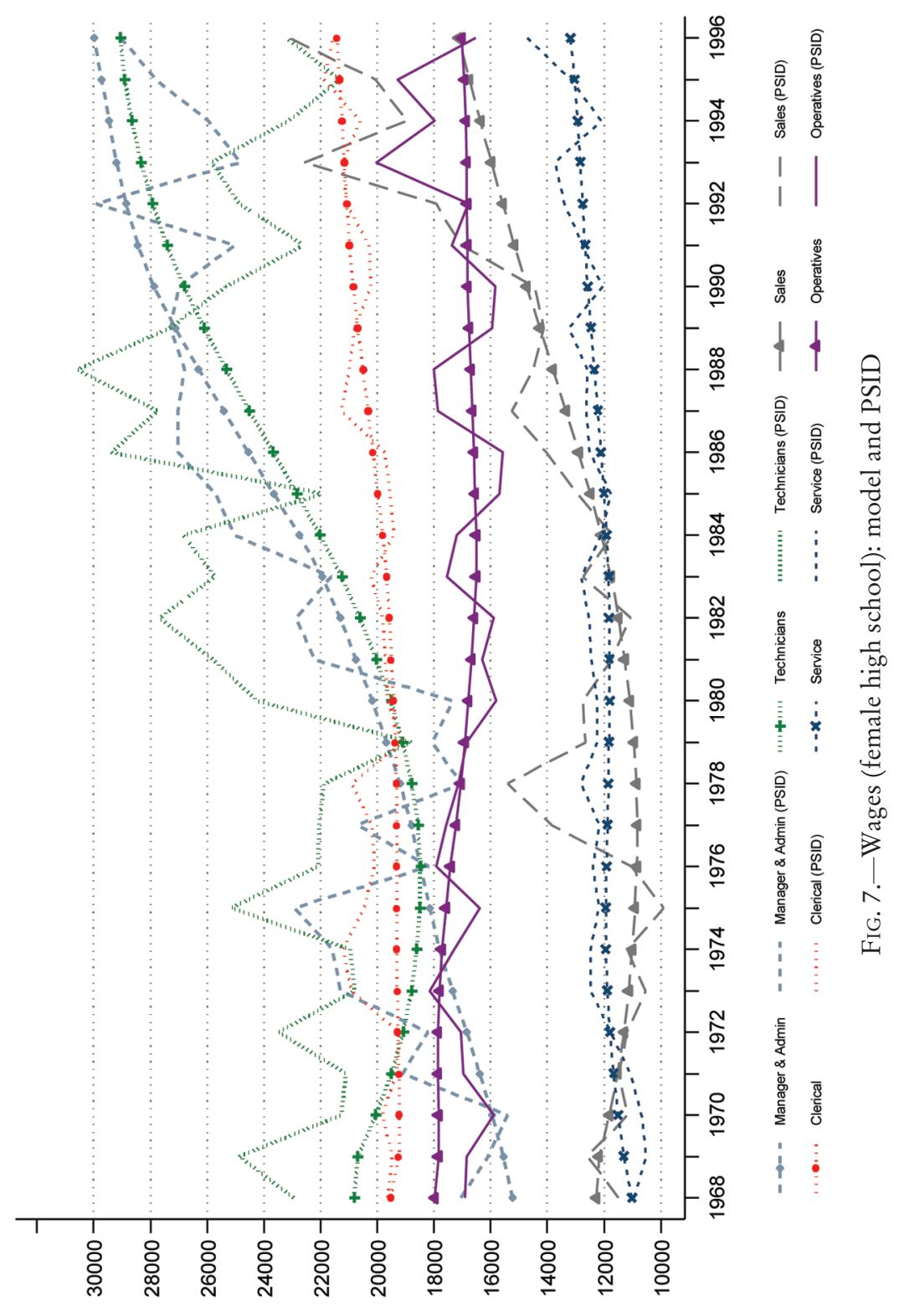


Finally, we consider college females. Their home share also fell sharply, from $58 \%$ in 1968 to $38 \%$ in 1996 . The model predicts a decline from $58 \%$ to $35 \%$ and also matches the time path accurately (see fig. F4). ${ }^{33}$ The occupations in which college women tend to work changed markedly as well (see fig. 8). In 1968 the largest occupations by far were technicians (15\%) and clerical $(14 \%)$. As only $42 \%$ of college women were employed, these occupations constituted $67 \%$ of their total employment. During the sample period the share of clerical stayed flat while that of technicians grew modestly to $20 \%$. Occupations that grew most were professionals, from $3 \%$ to $9 \%$; managers, from $4 \%$ to $9 \%$; and sales, from $1 \%$ to $5 \%$. (It is notable that neither college nor high school females moved in large numbers into "maledominated" blue-collar occupations.)

The wages of college women in the professional and managerial occupations trend up throughout the sample period $(+33 \%$ and $+30 \%$, respectively; see fig. 9). This is in contrast to the pattern for college men, where, as noted earlier, wages in these occupations trend down until about 1983 and up thereafter, ending in 1996 about where they started. In the clerical occupation, wages of college women were flat, while for college men they fell sharply $(-20 \%)$. And wages of college women grew sharply in sales, while for college men they were flat. The model fits all the patterns in wages and employment for college women quite well. The sharp contrast with patterns for college men is hard to rationalize if genders are perfect substitutes.

Figures F5 and F6 break down the changes in wages of college versus high school workers by gender and age. For men, we see the striking fact, noted by Card and Lemieux (2001), that the increase in the college premium was concentrated among younger workers. For 25-34-year-olds, the college premium increased from 1.33 in 1980 to 1.60 in $1996 . .^{34}$ But for the other three age groups no such trend is apparent. The model captures these patterns.

For women, the situation is somewhat different. For 25-34-year-olds, the college premium increased from 1.37 in 1980 to 1.55 in 1996. But the college premium increased for 45-54-year-olds as well, from 1.33 to 1.57 . But for them, the college premium was roughly 1.76 in 1968 , so it actually fell over the sample period as a whole. The other two age groups do not reveal such patterns. Again, the model captures all these features of the data quite well. Finally, in the next section, we consider changes in the overall college wage premium for men and women.

${ }^{33}$ The model predicts that home shares of females will cease declining after 1996. They rise slightly to a plateau of about $37 \%$ in 2011 for college females and $48 \%-49 \%$ for high school females. This appears roughly consistent with recent data.

${ }^{34}$ Note that for 25-34-year-old males, average annual earnings for college and high school workers in 1980 were roughly $\$ 44,000$ and $\$ 33,000$, a ratio of 1.33 . The figures for 1996 are $\$ 48,000$ and $\$ 30,000$, a ratio of 1.60 . 


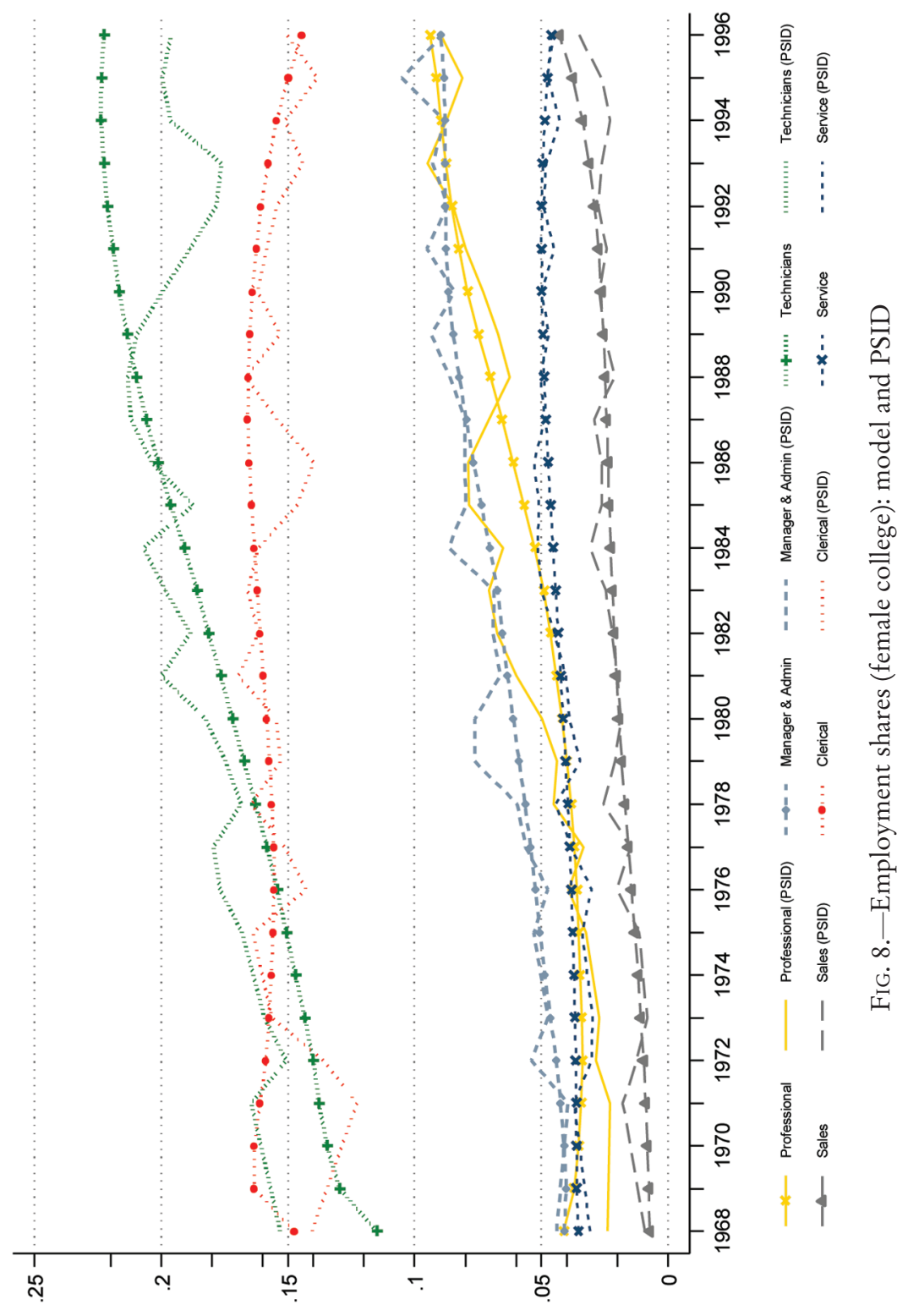




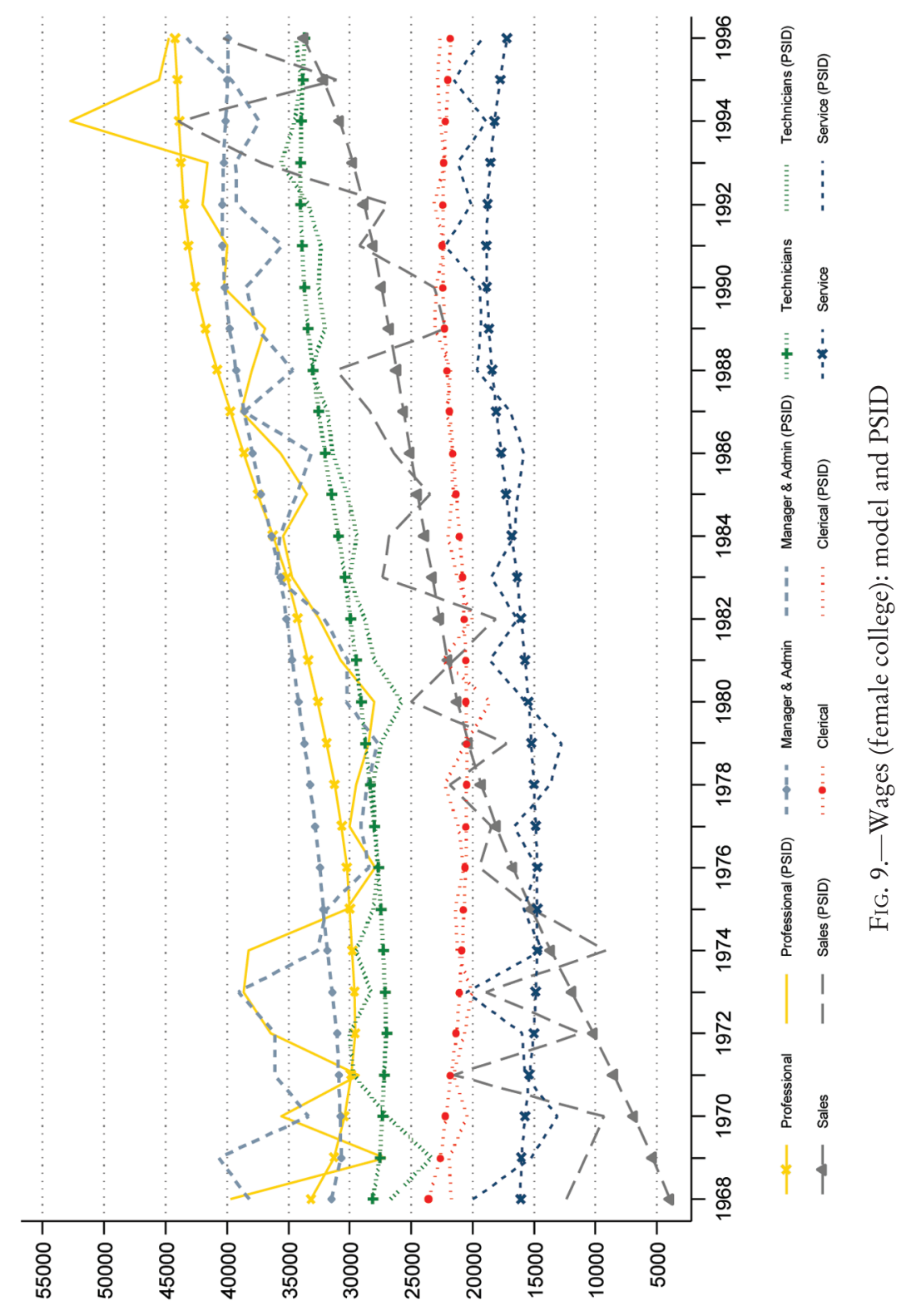




\section{Counterfactual Simulations-Factors Driving the College Wage Premium}

Table 6 reports a set of counterfactual simulations designed to shed light on key factors driving the college/high school wage premium. In the PSID, the male college premium dropped from $60 \%$ in 1968 to a trough of $37 \%$ in 1976. It then rose sharply to $70 \%$ in $1996 .{ }^{35}$ For women the premium was $58 \%$ in 1968 - close to that for men-but it behaved quite differently over time. It fell to a trough of $45 \%$ in 1974 (well above the $37 \%$ for men), rose to a peak of only about $57 \%$ in 1987 , and was flat from 1988 to 1996 (in contrast to the continued rise for men).

The model captures these patterns very accurately: In the baseline simulation for men, the college premium falls from $59 \%$ in 1968 to a trough of $38 \%$ in 1977 . It then rises to $50 \%$ in 1985 and $73 \%$ in 1996 . For women, the college premium is $58 \%$ in 1968, falls to $49 \%$ by 1977 (half the drop for men), rises to $57 \%$ in 1985 , and then stays fairly flat (reaching $59 \%$ in 1996).

We emphasize that the college premium for women was no higher in 1996 than in 1968. This is embarrassing for the SBTC story (even if augmented to include increasing demand for female labor, as in Katz and Murphy [1992]). SBTC implies an increasing college premium for women, not just for men. The reason that the college premium did not rise for women is that, as we have seen, high school women did rather well over this period. The different behavior of the college premium for men versus women highlights the importance of treating them as imperfect substitutes in production in order to explain changes in the wage structure.

In our first experiment, we hold all CES share parameters fixed at 1977 levels from 1977 onward. This removes any contribution of skill/occupation/gender/age-biased technical change (or demand shifts) to changes in the wage structure in the post-1977 period. For men, the college premium increases from $38 \%$ in 1977 to $56 \%$ in 1996 in the experiment, compared to $73 \%$ in 1996 under the baseline. Thus, the model implies that technical change/demand shifts explain $73-56=17$ out of the 35 -point increase in the college premium from 1977 to 1996.

But the difference between the 1977-85 and 1985-96 subperiods is striking. In the first period, the model predicts that the male college premium would have fallen 9 points in the absence of technical change. But in the

${ }^{35}$ What the college premium did in the 1990s is controversial. In the March CPS, Card and DiNardo (2002) find that it was flat for males. But Eckstein and Nagypal (2004), Beaudry and Green (2005), and Autor, Katz, and Kearney (2008) find that it continued to rise. Results are sensitive to data issues, such as handling top-coded CPS earnings. Our college premium measure grew more than what these authors report. The reason may be that we have only two types of labor, so high school dropouts are grouped with "high school" and postgraduates are grouped with "college.” As Eckstein and Nagypal find, postgraduate wages grew more than college wages, and dropout wages fell relative to high school wages. 
Table 6

Counterfactual Experiments: The College/High School Wage Premium under Alternative Scenarios

\begin{tabular}{|c|c|c|c|c|c|c|c|}
\hline \multirow{4}{*}{$\begin{array}{l}\text { Fix CES share parameters at } \\
\text { values for }\end{array}$} & \multirow[b]{2}{*}{1968} & \multirow[b]{2}{*}{1977} & \multirow[b]{2}{*}{1985} & \multirow[b]{2}{*}{1996} & \multicolumn{3}{|c|}{ Changes } \\
\hline & & & & & 1977-85 & 1985-96 & 1977-96 \\
\hline & & & & & & & \\
\hline & \multicolumn{7}{|c|}{ Males } \\
\hline \multirow{4}{*}{$\begin{array}{l}\text { Baseline } \\
1977 \\
\text { Implied impact of } \\
\text { technical change }\end{array}$} & 1.593 & 1.378 & 1.498 & 1.727 & +12 & +23 & +35 \\
\hline & & 1.378 & 1.289 & 1.561 & -9 & +27 & +18 \\
\hline & & & & & $(-2)$ & $(+21)$ & $(+19)$ \\
\hline & \multicolumn{7}{|c|}{ Females } \\
\hline \multirow{5}{*}{$\begin{array}{l}\text { Baseline } \\
1977 \\
\text { Implied impact of } \\
\text { technical change } \\
\text { Fix tastes for college at values } \\
\quad \text { for }\end{array}$} & \multirow[t]{3}{*}{1.584} & \multirow{3}{*}{$\begin{array}{l}1.492 \\
1.492\end{array}$} & 1.572 & \multirow{3}{*}{$\begin{array}{l}1.589 \\
1.379\end{array}$} & \multirow{2}{*}{$\begin{array}{c}+8 \\
-17\end{array}$} & \multirow{2}{*}{$\begin{array}{l}+2 \\
+6\end{array}$} & \multirow{2}{*}{$\begin{array}{l}+10 \\
-11\end{array}$} \\
\hline & & & 1.316 & & & & \\
\hline & & & & & $(+25)$ & $(-4)$ & $(+21)$ \\
\hline & & & & & & & \\
\hline & \multicolumn{7}{|c|}{ Males } \\
\hline \multirow{3}{*}{$\begin{array}{l}1968 \\
\text { Implied impact of tastes } \\
\text { for college }\end{array}$} & \multirow[t]{2}{*}{1.593} & \multirow[t]{2}{*}{1.387} & \multirow[t]{2}{*}{1.527} & \multirow[t]{2}{*}{1.546} & +14 & \multirow{3}{*}{$\begin{array}{l}+2 \\
(-4)\end{array}$} & \multirow{2}{*}{$\begin{array}{r}+16 \\
(+17)\end{array}$} \\
\hline & & & & & $(+21)$ & & \\
\hline & \multicolumn{6}{|c|}{ Females } & \\
\hline \multirow{2}{*}{$\begin{array}{l}1968 \\
\text { Implied impact of tastes } \\
\text { for college }\end{array}$} & \multirow[t]{2}{*}{1.584} & \multirow[t]{2}{*}{1.496} & \multirow[t]{2}{*}{1.562} & \multirow[t]{2}{*}{1.412} & +7 & -15 & -8 \\
\hline & & & & & $(+1)$ & $(+17)$ & $(+18)$ \\
\hline $\begin{array}{l}\text { Fix value of outside option } \\
\text { (females) at value for }\end{array}$ & & & & & & & \\
\hline & & & & & les & & \\
\hline 1968 & 1.593 & 1.379 & 1.502 & 1.733 & +12 & +23 & +35 \\
\hline $\begin{array}{l}\text { Implied impact of female } \\
\text { labor supply }\end{array}$ & & & & & $(0)$ & $(0)$ & $(0)$ \\
\hline & & & & Fer & ales & & \\
\hline $\begin{array}{l}1968 \\
\text { Implied impact of female }\end{array}$ & 1.584 & 1.483 & 1.550 & 1.557 & +7 & +1 & +8 \\
\hline labor supply & & & & & $(+1)$ & $(+1)$ & $(+2)$ \\
\hline
\end{tabular}

1985-96 period the model predicts that the male college premium would have risen 27 points even with no technical change. Thus, the model implies that technical change was a key force driving up the premium from 1977 to 1985 but not a major factor from 1985 to 1996.

Now consider the pattern for women. With technology fixed at 1977 levels, the model predicts that the college premium would have fallen 11 points from 1977 to 1996, compared to a baseline increase of 10 points. 
Thus, technical change accounts for a 21-point increase in the college premium for women. As technical change can "explain" $200 \%$ of the increase, the rise in the college premium for women was substantially dampened by other factors.

Again, the difference between the 1977-85 and 1985-96 periods is striking. In the earlier period the model predicts that without technical change the college premium would have fallen 17 points, compared to the observed 8 -point increase. But in the latter period the model predicts only a small increase in the college premium for women, with or without technical change. So again, as with men, technical change was much more important in the earlier period.

As is clear from figure 1, college attendance rates were very high in cohorts that made college attendance decisions in the late 1960s and entered the labor market in the early 1970s. But shortly thereafter they fell quite quickly. Card and Lemieux (2001) argued that this reduced supply of college graduates was an important factor driving up the college wage premium. In our second experiment, we hold tastes for college fixed at the 1968 levels. In light of the discussion of Section VI, the main implication is that college attendance rates will rise substantially among women (while remaining relatively stable for men). Of course, this will also affect men because, as discussed in Section IV.A, college men and women are highly substitutable.

For men, under the experiment, the increase in the college premium over the whole 1977-96 period is 16 points, compared to 35 points under the baseline. Thus, the "stagnation" of the flow of college graduates starting in the early 1970s does explain a large fraction of the growth in the college wage premium. ${ }^{36}$ Note also that the experiment has almost no effect on the college premium in the first period (1977-85). But in the latter period (1985-96) there would have been almost no growth in the college premium if college enrollment had grown as expected given 1968 preferences. These results appear broadly consistent with the Card-Lemieux argument.

For women, the pattern is very similar. With preferences fixed at 1968 levels, the model predicts that the college premium would have actually fallen 8 points over the whole 1977-96 period (compared to the 10-point increase in the baseline). As with men, the impact of the increased supply of college labor under the experiment arises entirely in the 1985-96 period.

Thus, the data appear broadly consistent with a pattern in which technical change/demand shifts drove up the college premium for both men and women in 1977-85, by 21 and 25 points, respectively, while relative scarcity of (mostly female) college labor drove up the college premium for both men and women in the 1985-96 period, by 21 and 17 points, respectively.

${ }^{36}$ It should be recalled, however, that the model does not explain why female tastes for college fell in this period. Those tastes are treated as unknown parameters. In Sec. VI we argued it is plausible that they actually reflect reduced marriage market returns to college. 
Finally, our third experiment looks at the effect of the substantial entry of women into the labor force over the 1968-97 period. Our model attributes this in part to rising wages and in part to a decline in the value of home time for women. The experiment holds the value of the home option fixed at the 1968 level, thus eliminating the supply shift. Strikingly, the increased supply of women had essentially no impact on the college premium for either men or women. In hindsight this is not surprising as college attendance rates were similar for men and women. Thus, the increased supply of women had little impact on the relative supply of college labor.

\section{Conclusion}

We have developed and estimated an equilibrium model of the US labor market using PSID data from 1968-96. A key feature of the model is that many types of labor, differentiated by education, gender, occupation, and age (giving 160 types), are treated as imperfect substitutes in production. We show that our model succeeds in fitting many aspects of the changing wage structure that are difficult to explain without treating all these groups as imperfect substitutes.

For example, within occupation/education cells, wages generally fell for high school men while rising for high school women. This is difficult to explain if men and women are perfect substitutes in production. Similarly, over the sample period as a whole the college premium rose only for younger males and females (it actually fell for females in the 45-54 age range). This is hard to explain if age groups are perfect substitutes.

Our model also succeeds in fitting a number of patterns that are difficult to reconcile with a simple SBTC story for the changing wage structure (even if augmented to include a demand shift toward female labor). Most notable is that high school females did so well, in terms of both wages and employment, relative to high school males..$^{37}$ Indeed, over the period as a whole, the college wage premium rose for men but not for women. This is an embarrassing pattern for the SBTC story as it should imply an increase in the college premium for both women and men.

Our model fits not just wages but occupational employment and college attendance rates. With a few exceptions, it fits patterns of wages, employment, and college attendance rather well for all 160 types of labor over the whole 29 -year period. ${ }^{38}$ It achieves this using six main factors: (i) our CES

${ }^{37}$ As Eckstein and Nagypal (2004) note, this is hard to reconcile with a view that the college premium rose because of a general increase in the skill rental price (especially as the relative supply of high school females rose substantially).

${ }^{38}$ One might argue that we should fit time paths of wages and employment well simply because we allow the share parameters to follow time polynomials. But we do not include any occupation/education/gender/age interactions. Thus, it is not at all obvious that we could obtain a good fit to wage and employment paths for all 160 types of labor. 
production function exhibits capital/skill complementarity; (ii) trends in CES share parameters imply increased labor demand in female-dominated service occupations relative to blue-collar; (iii) the high school share falls dramatically in six out of 10 occupations and modestly in two others (but not in clerical, the largest occupation for high school females); thus, a form of SBTC (i.e., increasing relative demand for college labor) is present in most occupations; (iv) the demand for males fell relative to females in 18 out of 20 occupation/education cells; (v) the value of home time fell for women, presumably capturing declining fertility; and (vi) female tastes for college trended down (consistent with reduced marriage market returns to college).

Notably, the share of the skilled labor aggregate did not increase, contrary to a simple SBTC story. Instead, factor ii illustrates the point made by Eckstein and Nagypal (2004) and Kambourov and Manovskii (2008, 2009a, 2009b) that occupational demand shifts are important for understanding changes in the wage structure. We find that occupation-specific demand shifts for different types of labor are also important (factors iii and iv). Factor iv could be called "gender-biased" technical change. This is plausible, for example, if women have better communication skills that are complements with improved communication technology. But it may also capture omitted factors, such as reduced discrimination or increased work experience of women within cells.

It is useful to contrast our results with those of Lee and Wolpin (2010). In their model, genders are perfect substitutes, so the gender wage gap falls because of skill upgrading: an exogenous decline in fertility and a demand shift toward services led women to expect to work more. So they invest more in human capital. But this may not adequately explain the growth of female relative wages within education/occupation cells or the failure of the college premium to increase for women. ${ }^{39}$

Finally, a success of our model is that, for males, it provides an explanation for the puzzle (noted by Card and Lemieux [2001]) that their college attendance rate stagnated from 1968 to 1990 despite a sharp increase in the college wage premium. And it does so without the need to resort to changing tastes for college. The point is that the expected lifetime earnings premium actually fell from 1968 to 1990 as a result of declining male labor force participation. This was due, in turn, to declining demand for labor in maledominated occupations.

Finally, two important limitations of our analysis are worth emphasizing. One is that we do not allow for skill heterogeneity within our $160 \mathrm{oc}-$

${ }^{39}$ Increased experience may explain part of the growth of female wages within cells, but in Sec. V we argued that, given plausible experience returns, it could not explain it fully. Also, employment increased by similar amounts for college and high school women. So this does not help explain why the college premium did not rise for women. 
cupation/education/gender/age cells. Thus, our model is silent on factors that may have led to increased inequality within these cells. Work that emphasizes heterogeneity includes Galor and Moav (2000) and Lee and Wolpin (2010). Another limitation is that we do not model on-the-job skill acquisition as in Heckman et al. (1998a, 1998b). As we have emphasized, these key simplifications allow us to handle many more types of labor than in these earlier studies. Future work should strive to unify these approaches in a tractable framework.

\section{References}

Arrow, Kenneth J., Hollis B. Chenery, Bagicha S. Minhas, and Robert M. Solow. 1961. Capital-labor substitution and economic efficiency. Review of Economics and Statistics 43, no. 3:225-50.

Autor, David, Lawrence Katz, and Melissa Kearney. 2008. Trends in U.S. wage inequality: Re-assessing the revisionists. Review of Economics and Statistics 90, no. 2:300-323.

Beaudry, Paul, and David A. Green. 2005. Changes in U.S. wages, 1976-2000: Ongoing skill bias or major technological change? Journal of Labor Economics 23, no. 3:609-48.

Berman, Eli, John Bound, and Zvi Griliches. 1994. Changes in the demand for skilled labor within U.S. manufacturing: Evidence from the Annual Survey of Manufactures. Quarterly Journal of Economics 59, no. 2:367-97.

Betts, Julian. 1996. What do students know about wages? Evidence from a survey of undergraduates. Journal of Human Resources 31, no. 1:27-56.

Bound, John, and George Johnson. 2002. Changes in the structure of wages in the 1980's: An evaluation of alternative explanations. American Economic Review 82, no. 3:371-92.

Card, David, and John DiNardo. 2002. Skill biased technical change and rising wage inequality: Some problems and puzzles. Journal of Labor Economics 20, no. 4:733-83.

Card, David, and Thomas Lemieux. 2001. Can falling supply explain the rising return to college for younger men? A cohort-based analysis. Quarterly Journal of Economics 116, no. 2:705-46.

Dominitz, Jeff, and Charles Manski. 1996. Eliciting student expectations of the returns to schooling. Journal of Human Resources 31, no. 1:1-26.

Eckstein, Zvi, and Eva Nagypal. 2004. The evolution of US earnings inequality: 1961-2002. Federal Reserve Bank of Minneapolis Quarterly Review 28, no. 2:10-29.

Fallon, P. R., and Richard Layard. 1975. Capital-skill complementarity, income distribution, and output accounting. Journal of Political Economy 83, no. 2:279-301. 
Galor, Oded, and Omer Moav. 2000. Ability biased technological transition, wage inequality and economic growth. Quarterly Journal of Economics 115 , no. 2:469-97.

Geweke, John F., and Michael P. Keane. 2000. An empirical analysis of male income dynamics in the PSID: 1968-1989. Journal of Econometrics 96, no. 2:293-356.

Gottschalk, Peter, and Robert Moffitt. 1994. Growth in earnings instability in the U.S. labor market. Brookings Papers on Economic Activity, no. 2, 217-72.

Heckman, James, Lance Lochner, and Christopher Taber. 1998a. Explaining rising wage inequality: Explorations with a dynamic equilibrium model of labor earnings with heterogeneous agents. Review of Economic Dynamics 1:1-58.

-1998b. General-equilibrium treatment effects: A study of tuition policy. American Economic Review 88, no. 2:381-86.

Juhn, Chinhui, Kevin Murphy, and Brooks Pierce. 1993. Wage inequality and the rise in returns to skill. Journal of Political Economy 101, no. 3: 410-42.

Kambourov, Gueorgui, and Iourii Manovskii. 2008. Rising occupational and industry mobility in the United States: 1968-1997. International Economic Review 49, no. 1:41-79.

- 2009a. Occupational mobility and wage inequality. Review of Economic Studies 76, no. 2:731-59.

. 2009b. Occupational specificity of human capital. International Economic Review 50, no. 1:63-115.

Katz, Lawrence F., and Kevin M. Murphy. 1992. Changes in relative wages, 1963-1987: Supply and demand factors. Quarterly Journal of Economics 107, no. 1:35-78.

Keane, Michael P., and Kenneth I. Wolpin. 2001. The effect of parental transfers and borrowing constraints on educational attainment. International Economic Review 42, no. 4:1051-1103.

-2010. The role of labor and marriage markets, preference heterogeneity and the welfare system in the life cycle decisions of black, Hispanic and white women. International Economic Review 51, no. 3:851-92.

Kranz, Daniel Fernandez. 2006. Why has wage inequality increased more in the USA than in Europe? An empirical investigation of the demand and supply of skill. Applied Economics 38, no. 7:771-88.

Krusell, Per, Lee E. Ohanian, Jose-Victor Rios-Rull, and Giovanni Violante. 2000. Capital-skill complementarity and inequality: A macroeconomic analysis. Econometrica 68, no. 5:1029-53.

Lee, Donghoon. 2005. An estimable dynamic general equilibrium model of work, schooling and occupational choice. International Economic Review 46, no. 1:1-34. 
Lee, Donghoon, and Kenneth I. Wolpin. 2006. Intersectoral labor mobility and the growth of the service sector. Econometrica 74, no. 1:1-46. 2010. Accounting for wage and employment changes in the U.S. from 1968-2000: A dynamic model of labor market equilibrium. Journal of Econometrics 156, no. 1:68-85.

Leslie, Larry L. 1984. Changing patterns in student financing of higher education. Journal of Higher Education 55, no. 3:313-46.

Manski, Charles. 1993. Adolescent econometricians: How do youth infer the returns to schooling? In Studies of supply and demand in higher education, ed. Charles Clotfelter and Michael Rothschild, 43-57. Chicago: University of Chicago Press.

Martins, Pedro S. 2006. The return to university degrees: The students' perspectives. Unpublished manuscript, Queen Mary, University of London.

Moscarini, Giuseppe, and Francis Vella. 2002. Aggregate worker reallocation and occupational mobility in the United States: 1976-2000. Working Paper no. W02/18, Institute for Fiscal Studies, London.

Murphy, Kevin M., and Finis Welch. 1992. The structure of wages. Quarterly Journal of Economics 107, no. 1:285-326.

National Center for Education Statistics. 2003. Digest of Education Statistics. Washington, DC: US Government Printing Office. 